\title{
THE EVOLUTION OF BRITISH CATTLE AND
}

THE FASHONING OF BREEDS

JAMGS WIL.SON, M.A, B.SE. 

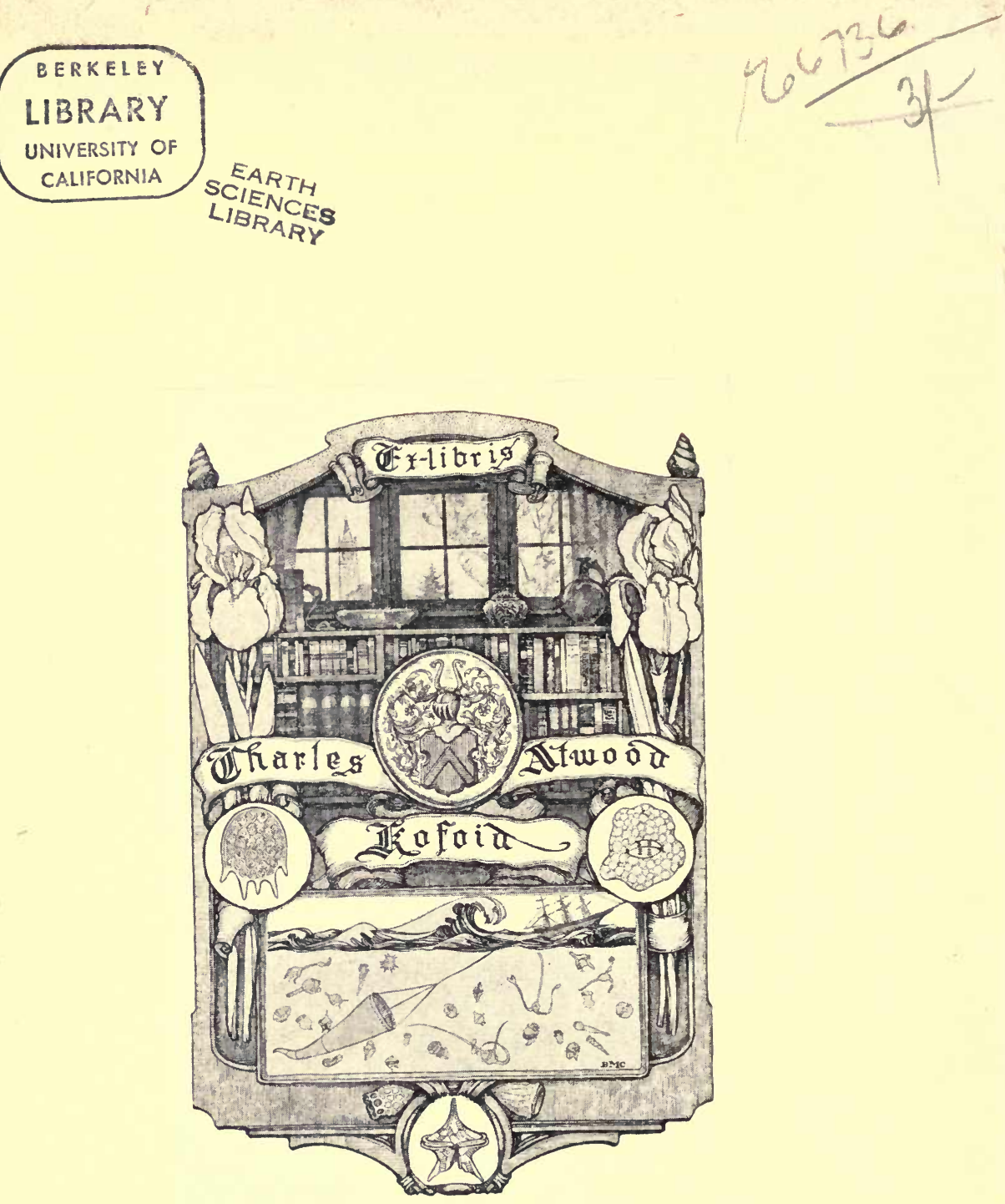


\section{GIFT Or \\ C. I. Camp}

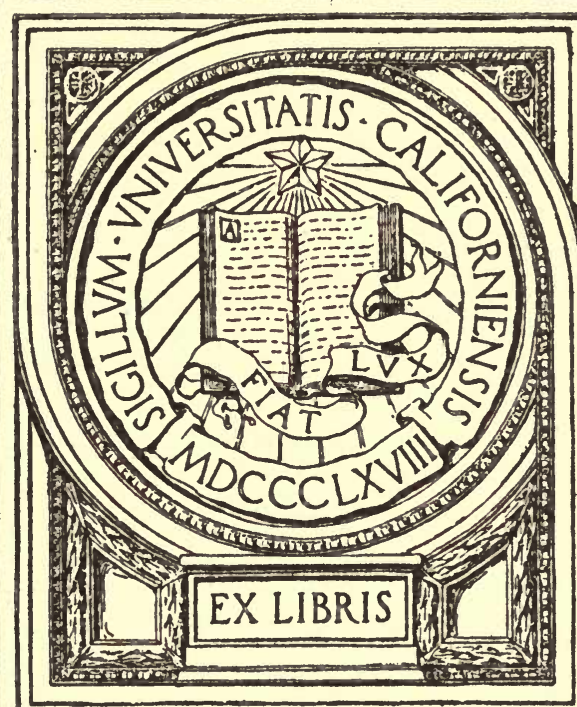

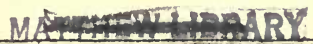

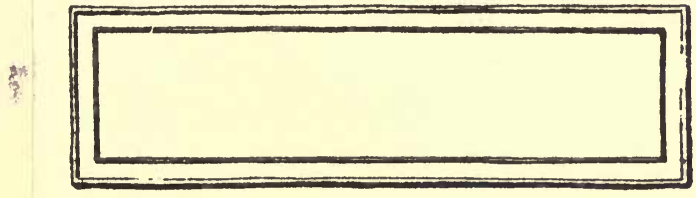



THE EVOLUTION OF BRITISH

CATTLE 



\title{
THE EVOLUTION OF
}

\section{BRITISH CATTLE}

\author{
AND

\section{THE FASHIONING OF BREEDS}

BY

JAMES WILSON, M.A., B.Sc.

PROFESSOR OF AGRICULTURE IN

THE ROYAL COLLEGE OF SCIENCE FOR IRELAND, DUBLIN

\section{LONDON}

VINTON \& COMPANY, LTD.

8, Bream's Buildings, Chancery Lane, E.C.

1909 


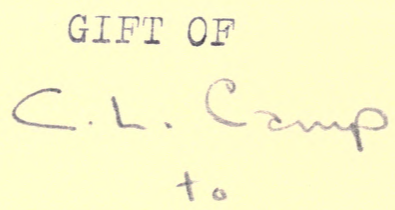

MATTHEW LIBRARY

$\therefore \vdots \because \because \because \because \vdots \vdots \therefore \cdots$ 


\section{CONTENTS}

I. PAGE

1. BOS PRIMIGENIUS • $• \cdot \cdot \cdot \cdot \cdot$ I

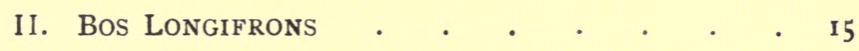

III. The Roman Contingent . . . . 25

IV. The ANGlo-Saxons . • . . . . $\quad 38$

V. The Norse Contingent. . . . . . 45

VI. The Dutch Invasion . . . . . . 70

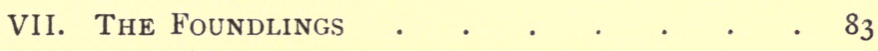

VIII. The Melting-Pot . . . . . . $\quad . \quad 88$

IX. The Dutch Supremacy . • . . . . IO2

X. BAKEWELl . • . . . . . . . . . IIO

XI. Blending AND SORTING • . • • • $\quad$ I 122

XII. Speculations . . . . . . . . . 136

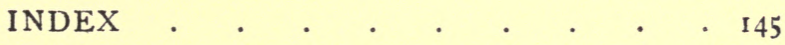





\section{LIST OF ILLUSTRATIONS}

Bos Primigenius, from Burwell Fen, Cambridge • i i

Bos Primigenius (Side View), from Burwell Fen,

CAMBRIDGE • . . . . . . . . . II

Bos LongIfRons, FROM SWEDEN . . . . . 17

Bos LONGIFRons, From SWITZERLAND . . . $\quad$. 18

Bos Longifrons, from Burwell Fen, Cambridge . 19

BOS LONGIFRONS, FROM IRELAND $\cdot$. . . 20

Romano-British SKull, with UptuRning Horn-CORES,

FROM REACH Fen, CAMBridge . . . . . 26

Roman Ox, from a Painting on a Wall in Pompeir. 29

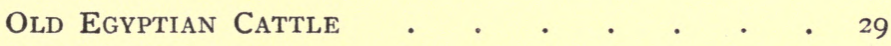

Sicilian OX

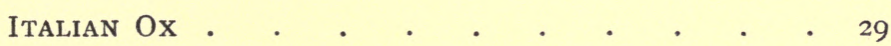

Ancient Egyptian Cattle $\cdot$. . . . . . 30

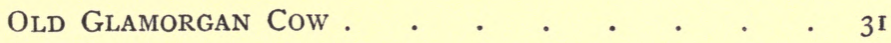

Abergavenny Bullock . . . . . . . 3 . 3

Old Derbyshire Bull . . . . . . . . 3 I

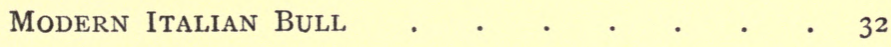

Chillingham Bull . . . . . . . . 32

MAP OF THE BRITISH ISLANDS SHOWING THE LOCATIONS OF the Herds in HaRTing's List and also the Approximate Direction of Green's Line • $\quad 36$ 
viii LIST OF ILLUSTRATIONS

The Durham Dun Cow . . . . . $\quad 5^{\text {Page }}$

Burghead Bulls . . . . . . . . . 63

Hornless Skull, from the Dunshaughlin Crannoge 63

Swedish FJÅLl Cow • • • • • • • • 69 


\section{EVOLUTION OF BRITISH CATTLE}

\section{I}

\section{BOS PRIMIGENIUS}

In this volume it will be our duty again and again to question, and sometimes to destroy, many fondly cherished beliefs as to the origin and history of the cattle of the British Isles, and also as to the manner in which nearly every breed has been evolved. Were our duty merely to destroy, it could be pleasant neither in its performance nor in the contemplation of its results; but it is to be hoped that no belief will be destroyed without a better one being put forward in its place. Little would be gained, for instance, by telling cattle owners that no British breed, excepting, perhaps, the Sussex, could lay serious claims to purity of blood in a long and unbroken stream, unless it could be shown that the most exalted breeds have attained their present eminence entirely through the mingling of diverse strains and races. Again, 


\section{EVOITTION OF BRITISH CATTLE}

it would only irritate the people of Durham to tell them that, when they set up a new cow in their cathedral in place of the one that had done duty for five hundred years, and when they took such care that "the horns were made this time of lead, lest she should ever again be reduced to the condition of a polled beast," they may have erred in assuming that the older cow had ever horns at all; although it might mollify them to know that the legendary cow that was the means of leading Saint Cuthbert's body to Durham was ornamented in a manner that neither the city nor the county of Durham need be ashamed of. And, although it may involve some risk to tell a Highland laird that the origin of his majestic breed is not "lost in the mists of antiquity," or the utilitarians of Aberdeen and Forfar that their thrifty blacks are descended from small, thinfleshed, narrow-backed, sickle-hocked, light-dun beasties, the risk may be minimised when it is shown that the cattle of the Gaelic-speaking Highlander in the west and the Scots-speaking Lowlander in the east can be traced back to those that accompanied their ancestors when they came over the North Sea a thousand years ago.

And we must play the Vandal at the very beginning with one of the most picturesque stories in which our cattle have ever played a part. Writers who have speculated upon the ancestry 
of British cattle have been struck by the phenomenon that, while the vast majority have been domesticated for many centuries, there still exists in England and Scotland a small number of herds which, though they have been enclosed in parks and thus far partially tamed, have never yet, to all appearance, been brought under the yoke.

At the present day these herds are few, but it has been shown that, in former times, such herds existed in certain parts of the country in considerable number. ${ }^{1}$ The likeness of these wild cattle to some of our domestic breeds has been frequently commented upon. Some writers have remarked their resemblance to the so-called creamy-white Highlanders, the white cattle of Wales, and the white-coloured Shorthorns ; others have noticed that their horns were like those of the black breeds of Ireland and Wales, and, in less degree, like those of the red-coloured cattle of Devon; while some have seen in these wild white cattle a strong resemblance, both in size and shape, to the modern Ayrshires.

These resemblances led many writers to conclude that the wild white cattle, and most of our domestic breeds, are of the self-same race, descended from the same original stock, and that, while in bygone times the ancestors of the domestic ones had been captured and tamed, the

1 Harting's "Extinct British Animals," 1880. 


\section{EVOLU'TION OF BRITISH CATTLE}

ancestors of the wild ones, by some lucky chance, had escaped the thrall of man.

The problem of tracing the ancestry of the whole was thus narrowed down to tracing that of a very few, and not only from their very picturesqueness, and the fact that they had never been tamed, but also because they had been referred to more than once in early writings, the wild white cattle afforded the most attractive clue.

The first step into the past was obvious and clear: it was to a spirited description of the Chillingham herd, written towards the end of the eighteenth century by Mr. Bailey, of Chillingham, and printed by George Culley in his "Observations on Live Stock":

"The wild breed, from being untameable, can only be kept within walls or good fences ; consequently very few of them are now to be met with, except in the parks of some gentlemen, who keep them for ornament, and as a curiosity ; those I have seen are at Chillingham-Castle, in Northumberland, a seat belonging to the Earl of Tankerville. Their colour is invariably of a creamy white; muzzle black; the whole of the inside of the ear, and about one-third of the outside, from the tips downwards, red; horns white, with black tips, very fine, and bent upwards; some of the bulls have a thin upright mane, about an inch and a half or two inches long. The weight of the oxen is from 35 to 45 st., and the 
cows from 25 to 35 st. the four quarters (i $4 \mathrm{lb}$. the stone).

"At the first appearance of any person they set off in full gallop, and, at a distance of about two hundred yards, make a wheel round and come boldly up again, tossing their heads in a menacing manner; on a sudden they make a full stop at a distance of forty or fifty yards, looking wildly at the object of their surprise, but upon the least motion being made, they all turn round, and fly off with equal speed, but not to the same distance, forming a shorter circle, and then returning with a bolder and more threatening aspect than before; they approach much nearer, probably within thirty yards, when they again make another stand, and again fly off. This they do several times, shortening their distance, and advancing nearer and nearer, till they come within such a short distance, that most people think it prudent to leave them, not chusing to provoke them further.

"The mode of killing them was perhaps the only modern remains of the grandeur of ancient hunting. On notice being given that a wild bull would be killed on a certain day, the inhabitants of the neighbourhood came mounted and armed with guns, etc., sometimes to the amount of an hundred horse, and four or five hundred foot, who stood upon walls or got into trees, 


\section{EVOLUTION OF BRITISH CATTLE}

while the horsemen rode off the bull from the rest of the herd till he stood at bay, when a marksman dismounted and shot. At some of these huntings twenty or thirty shots have been fired before he was subdued. On such occasions the bleeding victim grew desperately furious, from the smarting of his wounds and the shouts of savage joy that were echoing from every side. But from the number of accidents that happened, this dangerous mode has been little practised of late years, the park-keeper alone generally shooting them with a rifled gun at one shot.

"When the cows calve, they hide their calves for a week or ten days in some sequestered situation, and go and suckle them two or three times a day. If any persons come near the calves, they clap their heads close to the ground and lie like an hare in form, to hide themselves ; this is a proof of their native wildness, and is corroborated by the following circumstance that happened to the writer of this narrative, who found an hidden calf, two days old, very lean and very weak. On stroking its head it got up, pawed two or three times like an old bull, stepped back a few steps, and bolted at his legs with all its force; it then began to paw again, stepped back, and bolted as before, but, knowing its intent, and stepping aside, it missed him, fell, and was so very weak that it could not rise, tho' it made several efforts: but it had done 
enough-the whole herd were alarmed, and, coming to its rescue, obliged him to retire; for the dams will allow no persons to touch their calves, without attacking them with impetuous ferocity."

The next step was longer, but it was none the less obvious. It was to the wild cattle roaming the forest in unstinted freedom before the Norman barons or their successors took to enclosing parks for the preservation of game. Mediæval conditions lingered longest in some parts of Scotland, and thence about ${ }_{1526} \mathbf{5 r o m}$ the pen of Hector Boece, came the picture that fascinated the imagination and indicated the path to be followed if the ancestors of the wild white cattle were to be found.

"At this toun began the grit wod of Calidon." This wod of Calidon ran fra Striveling, throw Menteith and Stratherne, to Atholl and Lochquabir, as Ptolome writtis in his first table. In this wod wes sum time quhit bullis, with crisp and curland mane, like feirs lionis, and thoucht they semit meek and tame in the remanent figure of thair bodyis, thay wer mair wild than ony uthir beistis, and had sic hatrent aganis the societe and cumpany of men, that thay come nevir in the wodis, nor lesuris quhair thay fand ony feit or haind thairof, any mony dayis eftir,

1 Bellenden's translation. See Low's "Domesticated Animals," p. 234. 


\section{EVOLUTION OF BRITISH CATTLE}

thay eit nocht of the herbis that wer twichit or handillit by men. Thir bullis wer sa wild, that thay wer nevir tane but slight and crafty laubour, and sa impacient that, eftir thair taking, they deit for importable doloure. Alse sone as ony man invadit thir bullis they ruschit with so terrible preis on him, that they dang him to the eird, takand na feir of houndis, scharp lancis, nor uthir maist penitrive wapinnis. . . . And thoucht thir bullis wer bred in sindry boundis of the Calidon Wod, now, be contiwal hunting and lust of insolent men, thay are distroyit in all partis of Scotland, and nane of thaim left but allanerlie in Cumarnald."

Nor can it be denied that the impression made by Boece was deepened by Sir Walter Scott-

"Through the huge oaks of Evandale,

Whose limbs a thousand years have worn, What sullen roar comes down the gale, And drowns the hunter's pealing horn?

"Mightiest of all the beasts of chase,

That roam in woody Caledon,

Crashing the forest in his race,

The Mountain Bull comes thundering on.

"Fierce on the hunter's quiver'd band,

$\mathrm{He}$ rolls his eyes of swarthy glow,

Spurns, with black hoof and horn, the sand,

And tosses high his mane of snow.

"Aim'd well, the Chieftain's lance has flown,

Struggling in blood the savage lies ;

His roar is sunk in hollow groan-

Sound, merry huntsmen ! sound the pryse."

1 Ballad of Cadzow Castle. 


\section{BOS PRIMIGENIUS}

The ancestors of the British wild cattle were therefore mighty and untameable monsters of unconquerable ferocity, and none could be found more likely than the Uri of the Hercynian forest in Western Germany. Cæsar describes three extraordinary animals there: first, a stag-like ox, with a horn springing from the middle of its forehead between the ears. Next, an elk with no knots or joints in its legs, ${ }^{1}$ which could not lie down. If it fell by accident it could not get up again, and, so, it must recline against trees by way of going to bed, a habit which was its undoing, for the Germans of those days undermined or weakened the trees and, so, captured the elks that leant against them and fell. Last, the Uri. ${ }^{2}$

"The third of these three beasts are called Uri. In size they are a trifle smaller than elephants; in kind, colour, and shape they are bulls. Great is their strength and great their speed; nor, having espied them, do they spare either men or beasts. They are sedulously captured in pits and slain: the young men hardening themselves by such toil and training themselves by this kind of sport: and they who have killed most Uri, proclaimed as such by the horns being exhibited in public, receive great commendation. But it is not possible to accustom the Uri to men or to tame them, not

1 Crura sine nodis articulisque habent.

2 "Gallic War," bk. vi. chapter xxviii. 


\section{IO EVOLUTION OF BRITISH CATTLE}

even though they are caught young. Their horns differ much in size, shape, and kind from those of our cattle. They are anxiously sought after, the lips mounted with silver, and used as cups at the most abundant banquets."

The final step was from Cæsar's Urus to a British relative whose occasional remains have been found in primeval Scots bogs and East Anglian fens and in alluvial and lacustrine deposits whose hospitality they have shared with the elephant, the rhinoceros, the hippopotamus, and other aforetime inhabitants of England and Scotland since Neolithic times. This ox was of gigantic proportions. McKenny Hughes ${ }^{1}$ describes it as "a large, gaunt beast with a long, narrow face." Fleming says," "Many of the skulls which occur in marl-pits in Scotland exhibit dimensions superior to those of the largest domestic breed. A skull in my possession measures twenty-seven inches and a half in length, and eleven inches and a half across the orbits." Owen, in describing a skull in the British Museum found near Atholl in Perthshire, says, "The skull is one yard in length and the span of the horncores is three feet six inches." ${ }^{3}$ The accompanying drawings, in McKenny Hughes's paper, from an ox of this kind "found in Burwell Fen, near

1 "On the more important Breeds of Cattle which have been recognised in the British Isles," I896, p. 6.

2 "History of British Animals," I 828, p. 24.

3 "British Fossil Mammals," I846, p. 501. 
Cambridge, with a polished stone implement sticking in its skull," ${ }^{1}$ will indicate the relationship that

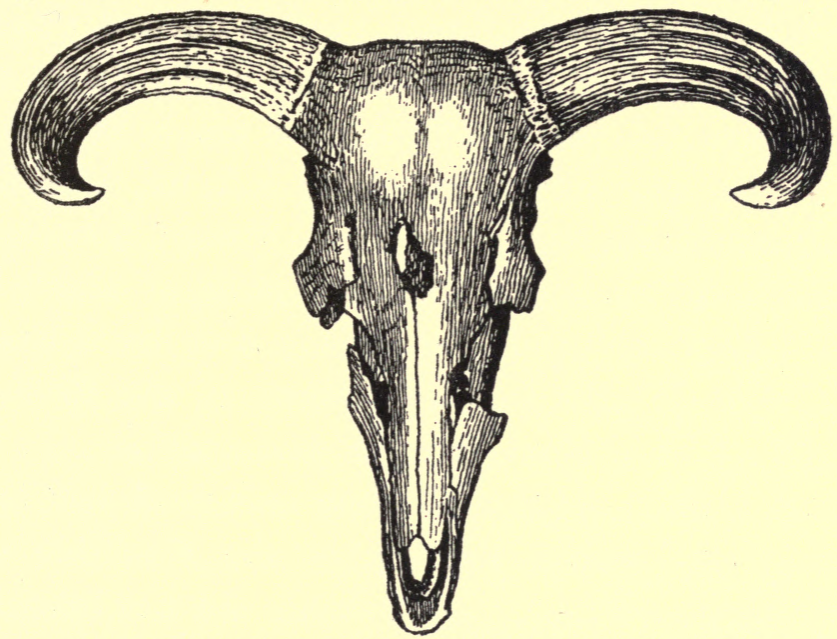

BOS PRIMIGENIUS, FROM BURWELL FEN, CAMBRIDGE.

[From McKenny Hughes.

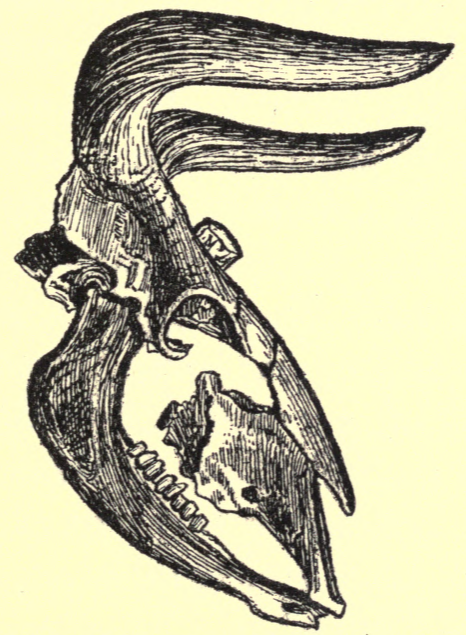

BOS PRIMIGENIUS (SIDE VIEW), FROM BURWELL FEN, CAMBRIDGE. [From McKenny Hughes.

subsisted between this animal and Neolithic man.

1 op. cit. 


\section{EVOLUTION OF BRITISH CATTLE}

What we are asked to believe is that our wild white cattle, and some at least of our domestic breeds trace back direct to this ancient giant, Bos primigenius. Sentiment and vanity tempt us to accept the belief, although we admit, in doing so, that our forefathers have left us a sadly degenerate legacy. We must dissent, however, from other considerations, the chief of which is that no remains of Bos primigenius have been found in deposits later than those of the Bronze Age. "The Urus or Bos primigenius ... is characteristic of the time when men used polished stone implements, that is, of the Neolithic or Newer Stone Age. It probably did not become extinct until the Bronze Age." 1

Even were the geological record less clear, it would still be difficult to prove that Bos primigenius was the ancestor of our modern cattle. The skeletal inconsistencies are too great. Leaving other considerations aside, and taking Fleming's measurements, which are the smallest, it is inconceivable that an animal whose skull was 27 inches long by II inches broad should be the ancestor of, say, the modern Shorthorn, an animal not much younger in time, whose skull is 23 or 24 inches long by I I or I 2 broad: that is, that the ratio of length to breadth should change from $\frac{2 \cdot 5}{1}$ to $\frac{2}{1}$.

It has been maintained that Bos primigenius

1 McKenny Hughes. 
may have crossed with his contemporary Bos longifrons, an animal about the size of a Kerry, and that some of our cattle are descended from the cross. Had such a cross taken place, cattle skeletally intermediate between Bos longifrons and Bos primigenius must have resulted; but of such there is no evidence; and Bos longifrons has remained essentially the same right through the period when he was contemporary with Bos primigenius down to the present time.

It has also been maintained by those who hold that the wild white cattle at least are descended from Bos primigenius, that they have deteriorated in size through confinement and consequent in-breeding. This presumes that they were giants at the time they were emparked. Had they deteriorated, as we are asked to believe, some of them in four or five centuries, some of them in two, such a phenomenon would not have escaped notice till the nineteenth century. And surely, since some herds were still at liberty centuries after others had been emparked, the contrast in size between the bond and the free would have been recorded had it been there to record. Besides, what evidence have we that cattle or any other polygamous animals deteriorate in size through in-breeding? As for Cæsar's Urus, Urochs, Aurox, Aurochs, the primeval ancestral bull, the father of the race: is it to be taken seriously? Then, so must his 


\section{EVOLUTION OF BRITISH CATTLE}

one-horned ox, and his jointless elk. But is it possible for the Urus to have lived in Germany so long after he was extinct in Britain? and if he lived in Cæsar's time, would he have been called the $U r$-ochs? Even so, was the Hercynian forest his likeliest habitation? It is far more easy to imagine either that some diplomatic and genial German had invented a tale to deter the great Roman general and please the imperial note-taker or that Cæsar was really describing the bison. 


\section{BOS LONGIFRONS}

Having driven off Bos primigenius, we ought now to follow up the wild white bull that led us off the scent ; but it will be more convenient to leave him alone for the present and pick him up again in his proper place.

We are told by those who collect and consider the records of the past-the geologist, the archæologist, and the historian-that the animals that have lived in Britain and Western Europe at one time and another have all migrated thither from the East. Bos primigenius, who was one of the early arrivals, came westward just before the Pleistocene, or Glacial period-“a prolonged period of cold broken up by shorter periods of milder climate" ${ }^{1}$-and he lived through that period and several sections of the next, in whose elucidation the geologist and the archæologist combine.

The earliest signs of man appear about the beginning of this next period, which is conveniently broken into sections or ages marked off

1 Sir Archibald Geikie's "Class-Book of Geology," 1897. 


\section{I6 EVOLUTION OF BRITISH CATTLE}

from each other by the degree of civilisation to which man had attained : viz. the Eolithic Age in which man makes use of only such tools as he picks up that are already shaped by Nature's hand, the Palæolithic Age in which he chips and fashions stones to suit his purpose, the Neolithic Age in which he works stones into shape by rubbing and polishing, and the succeeding Ages of Bronze and Iron.

The man of the Neolithic Age was not only a far later arrival than those who had lived before him, but his civilisation was at a very much higher level. According to Boyd Dawkins, "The population" of Britain "was probably large, divided into tribal communities possessed of fixed habitations, and living principally on their flocks and herds, acquainted with agriculture, and subsisting in a lesser degree by hunting and fishing. The arts of spinning, weaving, mining, and pottery-making were known, and that of boatbuilding had advanced sufficiently far to allow of voyages being made from France to Britain, and from Britain to Ireland." ' That man still hunted the beasts of the forest is proved by the ox in theW oodwardian Museum "with a polished stone implement sticking in its skull," but the state of his larder depended no longer upon his success with the Urus, since another much smaller ox had come westward with Neolithic man, and, 
according to Boyd Dawkins and Rütimeyer, was already in the domesticated state. ${ }^{1}$ At any rate, the remains of this little ox, which Owen called Bos longifrons because of the great depth of his forehead, have been found in Britain and Western Europe in all kinds of deposits from Neolithic down to the beginning of historic time; and, if he was not brought into Britain in the domestic state, he eventually became the domestic ox of

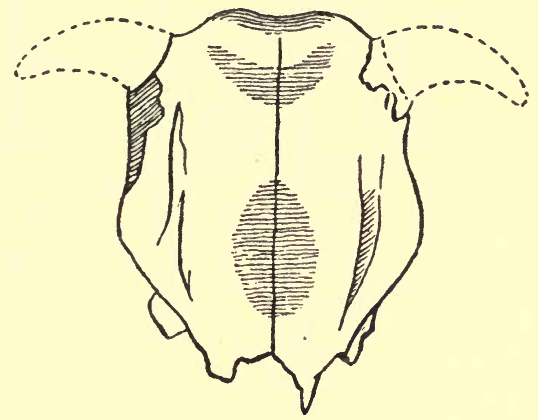

BOS LONGIFRONS, FROM SWEDEN.

[From Nilsson.

the pre-Roman inhabitants, for no other kind was brought into the country previous to the Roman Invasion. Cattle could only have been imported from the opposite shores of France and Belgium, and there they belonged to the self-same race. Bos longifrons "is the native breed with which we must start in all our speculations as to the origin and development of British oxen. The Romans found that breed here and no other." ${ }^{2}$

1 Ibid., p. 26r, and "Encyc. Brit.," v. 245.

2 McKenny Hughes, op. cit. 


\section{8 EVOLUTION OF BRITISH CATTLE}

Bos longifrons has been reconstructed again and again from his resurrected skeleton. From Swedish skeletons Nilsson describes him thus ${ }^{1}$ : "This is the smallest of all the ox tribe which lived in a wild state in our portion of the globe. To judge from the skeleton, it was 5 feet 4 inches

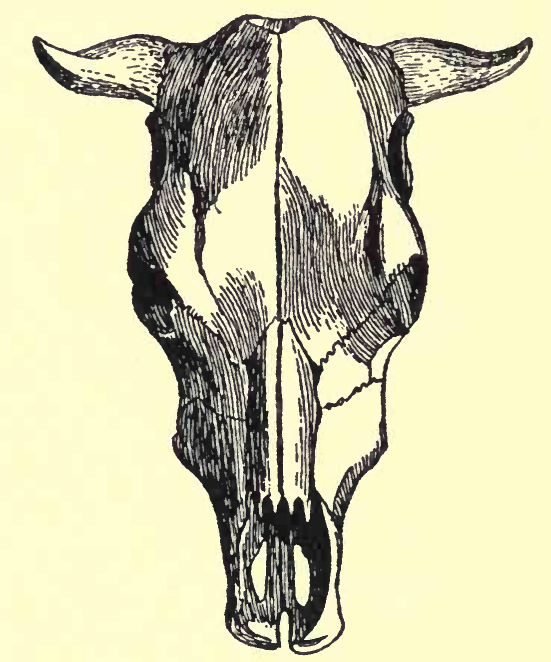

BOS LONGIFRONS-FROM SWITZERLAND.

From Rütimeyer.

long from the nape to the end of the rump bone, the head about I foot 4 inches, so that the whole length must have been 6 feet 8 inches. From the slender make of its bones, its body must rather have resembled a deer than our common tame ox; its legs at the extremities are certainly somewhat shorter and also thinner than those of

1 "Annals and Magazine of Natural History," vol. iv. second series, $1849, \mathrm{p} .352$. 
a crown-deer (full-antler'd red deer)." Rütimeyer calls it the peat cow, and, from specimens found in Swiss late dwellings, describes it thus ${ }^{1}$ : "The race which clearly predominated through the whole Stone Age and was found chiefly, though not exclusively, in the formations which we, upon other grounds, reckon among the oldest in

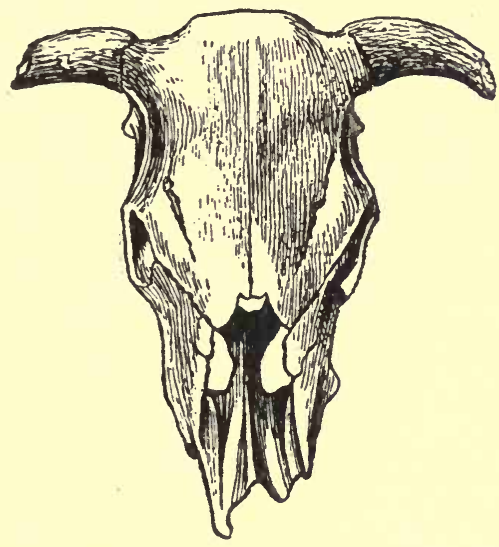

BOS LONGIFRONS, FROM BURWELL FEN, CAMBRIDGE.

[From McKenny Hughes.

Wangen and Mooseedorf, I may safely call the Peat Race, or the Peat Cow. Its chief characteristic, as shown by its remains, apart meantime from the skull, is the small length and height of its body, and the exceptionally short but remarkably fine and delicate limbs, right from the shoulder to the extreme terminal phalanges, which apparently carried very small hoofs."

From British and Irish skeletons, Owen

1 Fauna der Pfahlbauten. 


\section{EVOLUTION OF BRITISH CATTLE}

writes ${ }^{1}$ that "This small but ancient species or variety of ox belongs, like our present cattle, to the subgenus Bos, as is shown by the form of the forehead, and by the origin of the horns from the extremities of the occipital ridge; but it differs from the contemporary Bos primigenius, not only by its great inferiority of size, being smaller than the ordinary breeds of domestic cattle, but also by the horns being proportionally

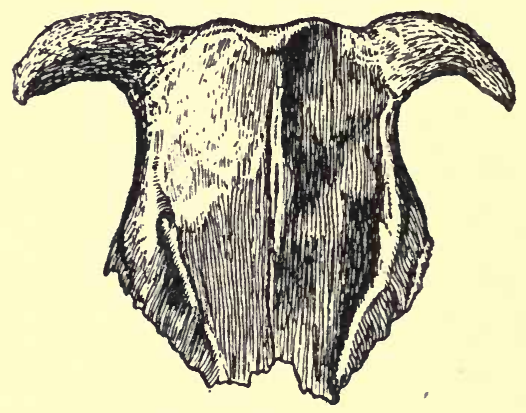

BOS LONGIFRONS, FROM IRELAND.

[From Owen.

much smaller and shorter, as well as differently directed, and by the forehead being less concave. It is indeed, usually flat; and the frontal bones extend further beyond the orbits, before they join the nasal bones, than in Bos primigenius. The horn-cores of the Bos longifrons describe a single short curve outwards and forwards in the plane of the forehead, rarely rising above that plane, more rarely sinking below it: the cores have a very rugged exterior, and are usually a little flattened

2 "British Fossil Mammals and Birds," p. 5 Io. 
at their upper part." McKenny Hughes, also from British and Irish skeletons, says ${ }^{1}$ that "Bos longifrons was a very small animal; probably not larger than a Kerry cow. It was remarkable for the height of its forehead above its orbits, for its strongly developed occipital region, and its small horns curved inward and forward."

There have also been speculations as to the colours of both these ancient oxen, but in neither case have they been based upon sure foundations. As regards Bos primigenius, the foundations were absolutely unsafe, for Cæsar's hint is of no value, even if we knew the colour that was in his mind when he wrote of the Uri that "in kind, colour, and shape they are bulls"; nor can the colour of an animal so long extinct be inferred from the great variety among the larger European breeds of the present day, were it even clear that these are the descendants of Bos primigenius. As to the colour of the pre-historic Bos longifrons, speculators are upon much safer ground, since many of his descendants are still alive. But there is always the difficulty of eliminating the colours of intruding races, or, of intruding breeds, in the case of some particular branch of the Bos longifrons race. Werner, ${ }^{2}$ who had the continental Bos longifrons chiefly in his mind, "describes the

1 Op. cit., p. 9.

2 "Ein Beitrage zur Geschichte des Europäischen Hausrindes," 1892. 


\section{EVOLUTION OF BRITISH CATTLE}

breed as a small form, of slender, almost graceful build. The hide is of a uniform yellowish-grey, grey, or brown tint, white patches being uncommon. Other characteristics are, a lighter streak round the muzzle, a light iris, a black stripe down the back, the lighter colour of the belly and the inner side of the legs, the occurrence of lighter coloured hair within the outer ear, and long hairs on the rim of it. The skin and muzzle are always black in colour." 1 While Boyd Dawkins, who dealt with the British Bos longifrons, came to the conclusion that the breed was usually of a dark colour probably black, red, and brindled. ${ }^{2}$ These authors inferred the colours of the original Bos longifrons from the colours of separate branches of his presumed descendants, while Boyd Dawkins also took into account some specimens of hair which have been found in prehistoric deposits. Both failed to allow for the effects of variation or of intruding breeds or races. With Werner's conclusions we have no immediate concern; but, as we shall see later, the reds and the brindles which Boyd Dawkins took to be the original natives of Britain were really intruders.

To show that the British variety of Bos longifrons was black, we must anticipate some part of what is to follow, on the understanding

1 Quoted from McKenny Hughes, op. cit.

2 "Cave Hunting." 
that what is now taken on credit will be made good hereafter. It is a well-known fact in human history that, as one race retires before another, the retiring and the invading races are usually accompanied by some part of their live stock, and above all by their cattle which, in earlier times, not only afforded food and clothing but took a chief share in tilling the earth, and thus were an outstanding necessity in man's existence. The Helvetii, and Cassievelaunus, the British chief who drove his people and their flocks into the woods on the approach of the Romans in Cæsar's time, and the Spaniards, the English, and the Boers in recent times might be referred to as examples. When the Celtic people retired before the English they carried their cattle along with them into the west and the north; and till this day, the cattle in the Celtic parts of Britain, which are descended from the cattle of the pre-Roman Celts, and through them from the pre-historic Bos longifrons, are predominantly black, and, as we look farther and farther into the past, we find the territory of these black cattle larger, and the regularity of their colour increasing. Till nearly the end of the seventeenth century, Scotland, Ireland, Wales, Cornwall, and the north of England were almost fully occupied by black cattle, among which there was a sprinkling of reds, whites, and brindles, and an occasional dun; in still earlier 


\section{EVOLUTION OF BRITISH CATTLE}

times the cattle of these other colours were rare enough to be of higher value. But the alien colours can all be accounted for. The whites were brought in by the Romans, the reds by the English, the brindles were the result of another importation, while the duns were one of the many things for which we have to thank the Norsemen. 


\section{III}

\section{THE ROMAN CONTINGENT}

Although the opinion that the wild white cattle were the untamed descendants of the mighty Urus was at one time widely believed, there grew up a body of dissenters, among whom Owen, ${ }^{1}$ Boyd Dawkins, ${ }^{2}$ and Dr. J. A. Smith ${ }^{3}$ were notable, who were sceptical, first, of our domestic cattle being descended from Bos primigenius; next, of the wild white cattle being descended from the same source; and, lastly, of these same wild white cattle being descended from wild cattle at all. The views of the sceptics were thus boldly expressed in Alston's "Fauna of Scotland," published in 1876: "To me the evidence appears overwhelmingly to prove that the modern park cattle are not wild survivors of the Urus, but are the descendants of a race which had escaped from domestication, and had lived a feral life till they were enclosed in the parks and chases of the mediæval magnates."

1 "British Fossil Mammals and Birds."

2 "Cave Hunting," and "Early Man in Britain."

3 "Notes on the Ancient Cattle of Scotland." 


\section{EVOLUTION OF BRITISH CATTLE}

The first to trace the white park cattle and white domestic cattle back to their source was Professor McKenny Hughes, of Cambridge. ${ }^{1}$ In the course of excavations " over areas long occupied by the Romans" he found a change coming over the remains of the cattle deposited there. He found evidence of a new breed mingling with the old. "The new breed is larger, the horn-

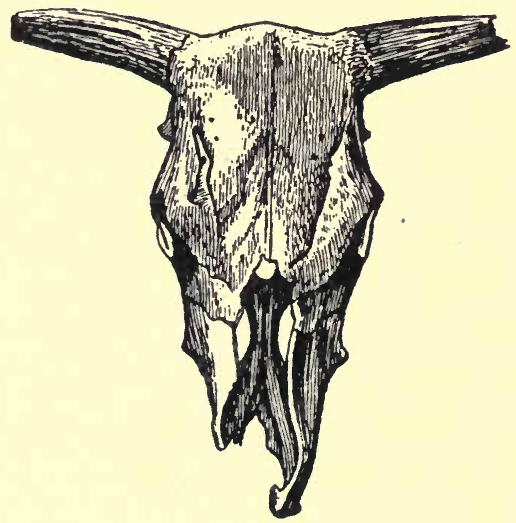

ROMANO-BRITISH SKULL, WITH UPTURNING HORN-CORES, FROM REACH FEN, CAMBRIDGE.

[From McKenny Hughes.

cores are stouter in proportion to their length, and, starting from the side of the head, have a tendency outward and upward, instead of having the strong forward curve of Bos longifrons. All intermediate sizes and shapes are found, from the small native to the new improved breed. . . The specimen I have figured "- the skull figured here-" was found in the peat near Reach Lode,

${ }^{1}$ See work already quoted. 
north of Cambridge. One remarkable fact is worth recording in relation to this skull. The peat-diggers, as their long trenches approached Reach Lode, always came upon a sort of bank, where the peat was harder and mixed with earthy material. This indicated that there had been a fosse dug through the peat to the underlying marl and clay, and that the bank was the upcast from this fosse. It was in the direct line from Reach to Upware, starting from near the great quarries which may date from Roman times, and from the end of the Devil's Ditch, along which so many remains have been found, and pointing straight for the southern end of the Upware island, where also there are abundant traces of Roman occupation. All the Roman pottery from this part of the fenland which I have been able to trace to its exact locality, was found along the line of this raised bank."

Starting from this hint, McKenny Hughes went on to inquire into the kind of cattle most likely to have been brought into Britain by the Romans. They could not have been the native cattle of France, for, being of the same type, these could have brought about no change in the character of the cattle in Britain. They must have come either immediately or originally from beyond the Alps. Having eliminated Italian cattle of recent introduction to Italy, and considered the evidence from coins and similar 


\section{EVOLUTION OF BRITISH CATTLE}

sources, McKenny Hughes came to the conclusion that the race which the Romans were most likely to have introduced to Britain was the large white race which, in ancient as in modern times, stretched eastwards and southwards into Asia and Egypt.

Could any resemblances be traced between the old white cattle of Southern Europe and those whose bones lay in the Roman rubbish heaps of Britain? And were their presumable descendants in any way alike? The first link was found in the fact that, while the horns of Bos longifrons curved forward and inward, the horns of the old southern cattle curved decidedly upward. So also, as shown by their cores, did the horns of the new breed that came into Britain with the Romans. Another link was found in the length and shape of the horns. The horns of the old southern cattle not only turned upward, but were lyre-shaped, with a peculiar final bend, and many of them were of extraordinary length. The same characteristics are found not only among modern breeds of this South European race, but also among English breeds descended certainly from cattle brought into the country within historical time, and, presumably, from those brought in by the Romans. The accompanying illustrations will make this point clear.

Another link was found in the fact that 


\section{THE ROMAN CONTINGENT}

the English park cattle and the South European race were of the same colour, viz. white with black "points"; that is, the body white, the muzzle and ears black, and the ears lined and

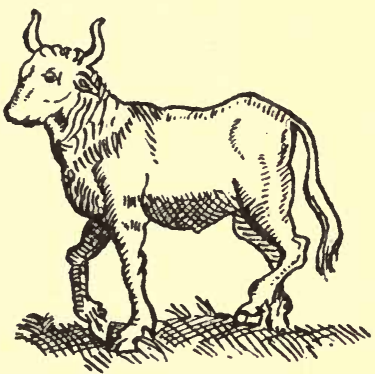

ROMAN OX, FROM A PAINTING

ON A WALL IN POMPEII. [From McKenny Hughes.

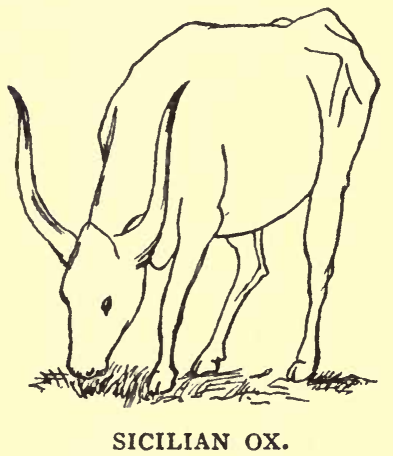

[From McKenny Hughes.

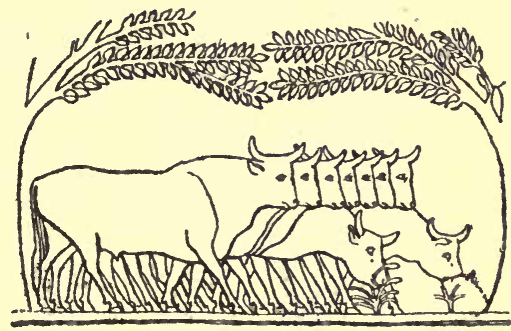

OLD EGYPTIAN CATTLE.

[From McKenny Hughes.

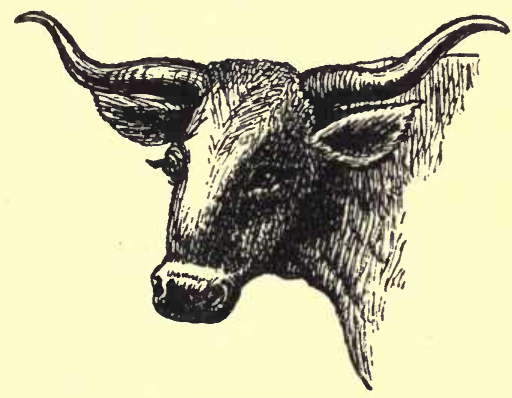

ITALIAN OX.

[From McKenny Hughes.

the muzzle encircled with black or brown hairs. Black or brown patches are sometimes found on other parts of the body and, frequently, below the knee. The extraordinary resemblance between the English park cattle and the cattle of 


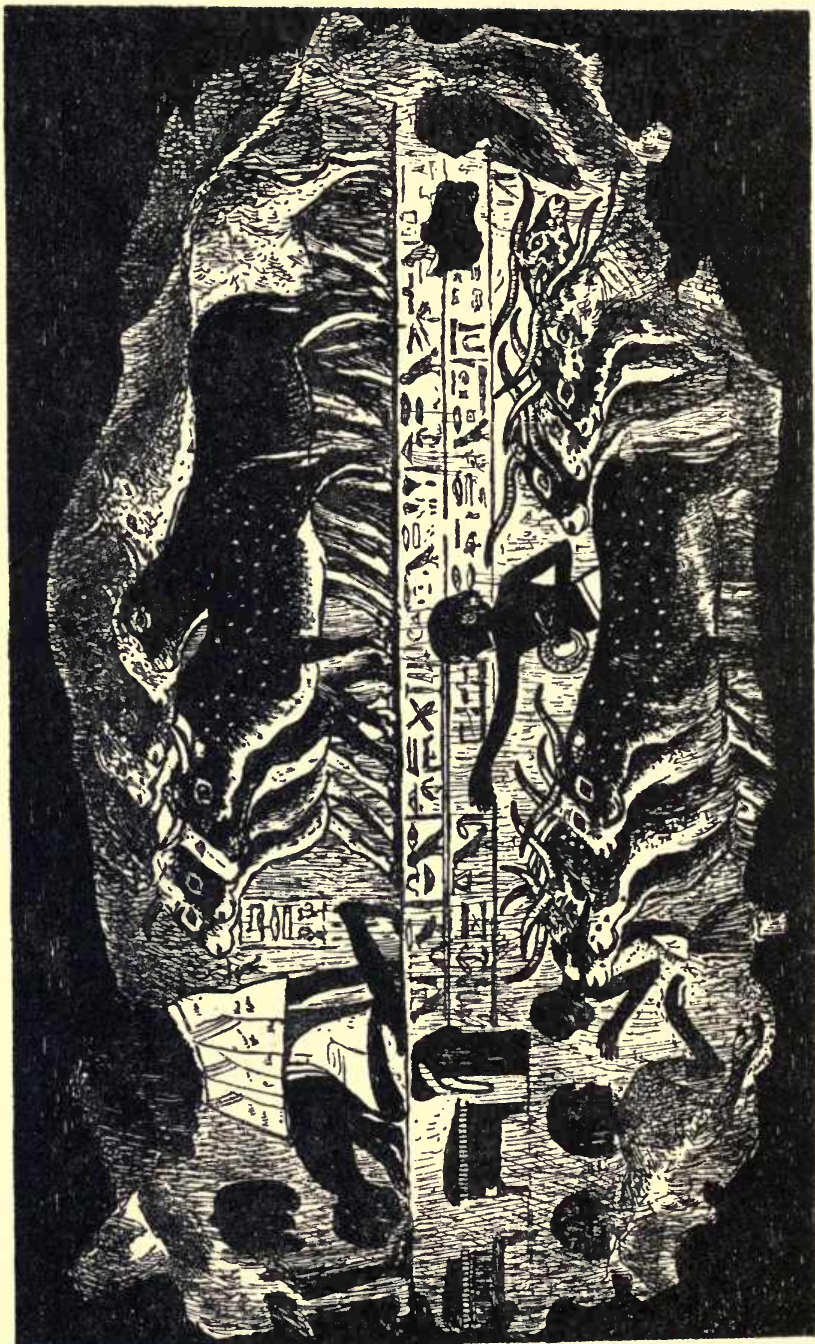

这

星 


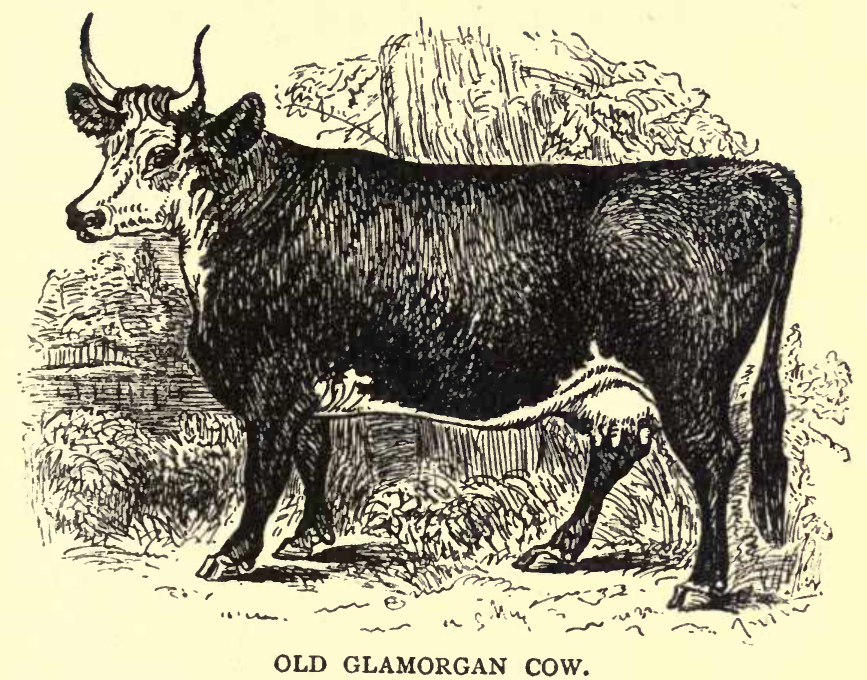

[From Youatt.

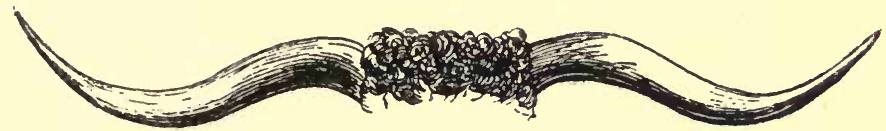

ABERGAVENNY |BULLOCK.

[From McKenny Hughes.

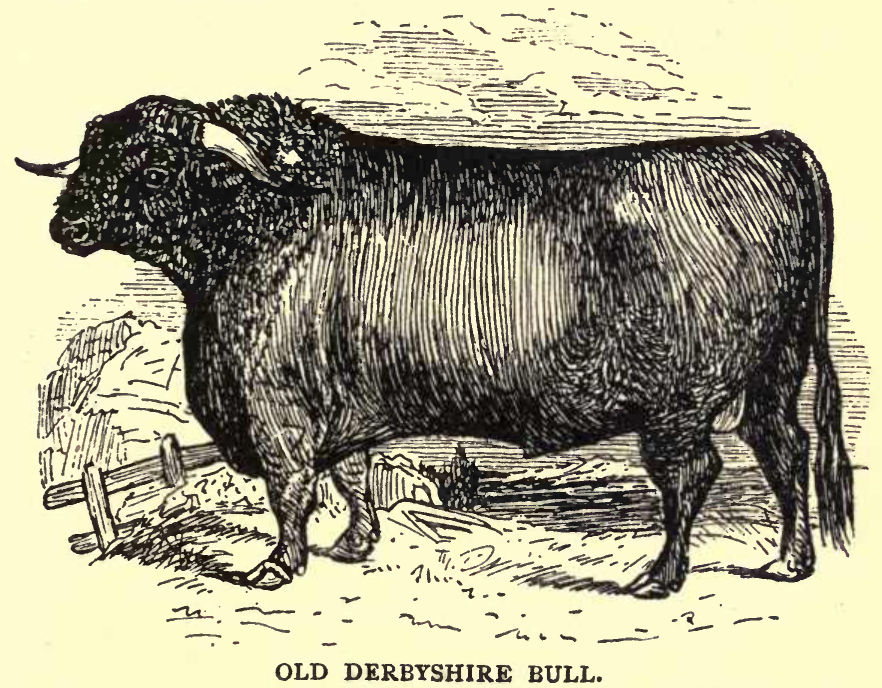

[From Youatt. 


\section{EVOLUTION OF BRITISH CATTLE}

modern Italy is thus expressed by McKenny Hughes " : "If a selection of the lighter coloured individuals of the common draught-ox of Italy were turned out in a park in England, no one would suspect that they did not belong to the wild white breed. ... A comparison of the skeleton of the Chillingham bull in the British Museum with that of an Italian bull presented by

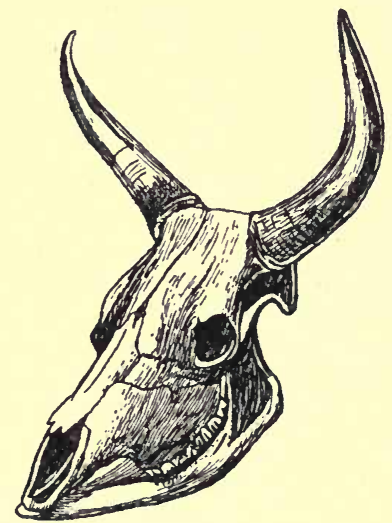

MODERN ITALIAN BULL.

[From McKenny Hughes.

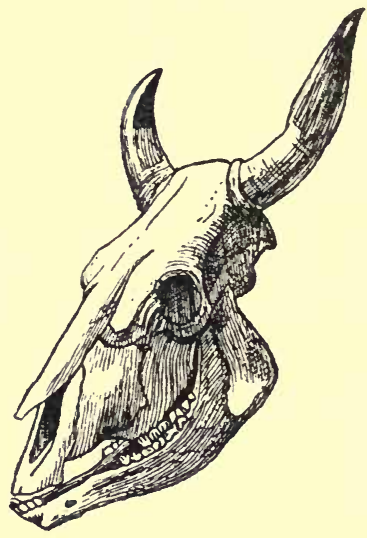

CHILLINGHAM BULL.

[From McKenny Hughes.

the King of Italy, shows that there is no essential difference between them."

A short consideration of a few other circumstances will make the connection between the two sets of cattle still clearer. A Roman colony was not altogether parallel to many of our modern colonies. The Romans in Britain were rather organisers of an empire than colonists. They did 
not drive away the Britons as the Europeans drove away the red Indians, but settled among them much as the English have settled in India. Their policy was to bring civilisation, industry, and commerce to the people they had conquered; to build towns and cities; to set up such a system of military stations as would secure their enterprise from enemies both within and without; and to lay down such a net-work of roads as would afford ready and easy communication between all parts of the country. Only a small proportion of the Romans took to farming, and these only in the neighbourhood of towns and military stations, or in districts with a comparatively dense and homogeneous Roman population. Consequently the Roman cattle were confined to the vicinity of towns and military stations, and, a large number being required for transport and other military purposes, it is inconceivable that many got into the hands of the natives.

The nature of the Roman evacuation of Britain is well known. It was almost a rout : a kind of forced march in which every impediment was left behind and only fighting gear and the minimum of food supplies were carried. The necessary transport animals were taken away, but cows and young stock, which would have been an insufferable encumbrance, were left behind. We know also the state of the country after the flight of the Romans; how the unsettled natives had 


\section{EVOLUTION OF BRITISH CATTLE}

little more than time to think of settling down when the Saxon was upon them. They managed to take possession of some of the cattle left behind by the Romans, but the rest were bound to have become feral. Then, as the natives were pushed westward and northward, the Roman cattle they had been unable to secure were left behind to fend for themselves in the forests. For some centuries more, the country from which the Celts had been expelled was the arena of strife and war, by no means thickly populated, and exposed on the western border to continual rieving and raiding. And, so, when the Normans came in, they found the Roman cattle no longer quiet and uncomplaining animals of burden, but wild and ferocious beasts of chase.

In connection with these white cattle, there is a series of facts which corroborates in a remarkable manner the views which have just been set forth. It is well known that the Romans had no hold upon Scotland north of the Grampians, and none at all upon Ireland. It is also well known that the English pressed into England from the Southern and Eastern coasts. That being so, these Roman cattle ought to have been confined to Wales, the North-west of England, and the South of Scotland. It is also well known that, while a large part of England was sunk in struggle and strife, during the Saxon period, Wales stood aside in comparative quiet. That also 
being so, we should expect the Roman cattle that were driven into Wales to have remained tame, while those that remained in England became feral. And our expectations are correct. The Roman cattle were confined almost without exception to the parts of the island indicated, and while they were tame in Wales they were feral in England and Scotland. And not only so, but Harting drew up a list of the places at which they are known to have been emparked, ${ }^{1}$ and every one of those places in England and Scotland is situated well on the west or just immediately to the east of what we may call Green's line: "The conquest of the bulk of Britain was now (about 588) complete. Eastward of a line which may be roughly drawn along the moorlands of Northumberland and Yorkshire, through Derbyshire and skirting the forest of Arden, to the mouth of the Severn, and thence by Mendip to the sea, the land had passed into English hands. From this time the character of the conquest of Britain had wholly changed. The older wars of extermination came to an end and as the invasion pushed westward in later times the Britons were no longer driven from the soil, but mingled with their conquerors." ${ }^{2}$

The accompanying map shows the locations

1 "British Animals Extinct within Historic Times," I88o.

2 "Short History of the English People," illustrated edition p. 29. 


\section{EVOLUTION OF BRITISH CATTLE}

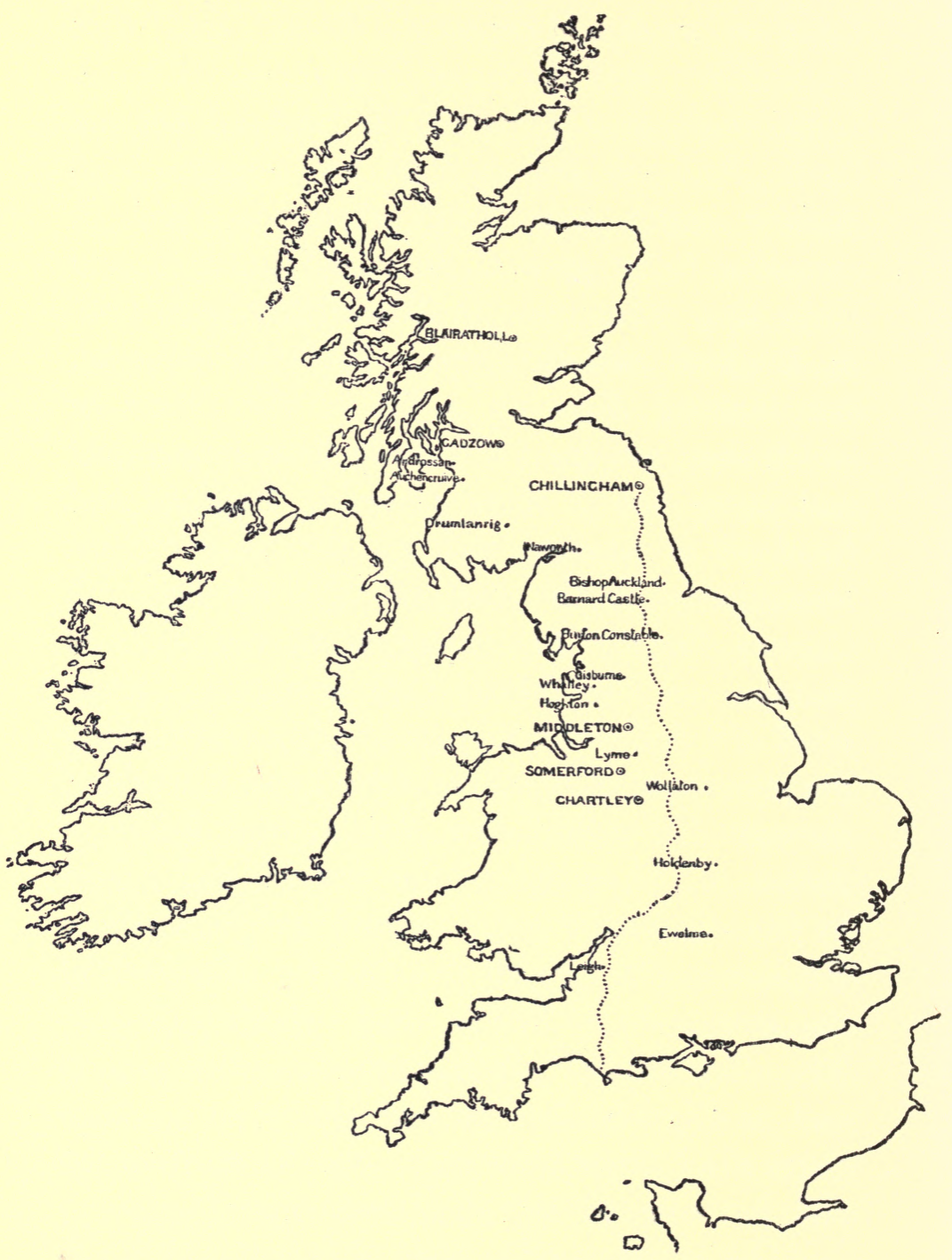

Map of the British Islands, showing the locations of the Herds in Harting's list, and also the approximate direction of Green's line. Existing herds are denoted by capital letters. 


\section{THE ROMAN CONTINGENT}

of the herds in Harting's list and also the approximate direction of Green's line. The herds that still exist are denoted by capital letters. The Blair Atholl herd has been removed to North Wales and the Middleton herd to Norfolk. Some of these herds are or were polled, a matter which will be discussed later. 


\section{THE ANGLO-SAXONS}

IF we remember the point made two chapters back that, in their migrations, human races are usually accompanied by their domestic animals, we know at once to look across the North Sea into Western Germany for the cattle that came in to fill up the gap left by the departure of the Celtic and Roman cattle into the west and the north. The nature of the English migration is first indicated in Bede's " Ecclesiastical History." The English were eventually an amalgamation of, at least, three tribes: the Jutes from what is now Jutland, the Angles from what is now Schleswig-Holstein, and the Saxons from the country south of that and westwards towards Holland and the Frisian islands. Bede, in telling from which of these tribes the people in different parts of England are descended, says : ${ }^{1}$ "From the Angles, that is, the country which is called Anglia, and which is said, from that time, to remain desert to this day, ${ }^{2}$ between the

1 "Ecclesiastical History," Bohn's edition, p. 24.

2 Bede lived from about 677 to 735 . 
provinces of the Jutes and the Saxons, are descended the East-Angles, the Midland-Angles," and so on, while John Richard Green, who might almost be said to have lived in this part of history, writes thus- ${ }^{1}$

"It was the slowness of their advance, the small numbers of each separate band in its descent upon the coast, that made it possible for the invaders to bring with them, when the work was done, the wives and children, the laet and the slave, even the cattle they had left behind them. The wave of conquest was thus but a prelude to the gradual migration of the whole people. For the settlement of the conquerors was nothing less than a transfer of English society to the shores of Britain. It was England that settled down on English soil."

But these quotations may not be sufficiently convincing that nearly the whole of the English part of England was wholly populated with English cattle, more especially as the cattle of Northumbria, which was one of the parts occupied by the Angles who, according to Bede, made the most complete migration, were still of the old black Celtic colour down to the beginning of the eighteenth century. But that is the only discrepancy, and it is not inexplicable; for in the days of the English invasion it was a far way to carry cattle from Schleswig to Yorkshire, 1 "The Making of England," p. 153. 


\section{EVOLUTION OF BRITISH CATTLE}

and, if only a few were carried, their colours would soon have been swamped by the dominant black of the natives.

The cattle in the rest of the English part of England were brought over by the invaders from Western Germany. To prove this statement we must show that the cattle in the south were different from those in the rest of England in Anglo-Saxon times, and also, if possible, that others of their kind had been left behind them in Germany. One fact must be borne in mind, namely, that, from the final settling down of the English till the junction of the seventeenth and eighteenth centuries there was very little movement of cattle or other live stock, with the exception of horses. We may therefore assume that, if a race of cattle is found occupying any particular part of the country about the end of the seventeenth or early in the eighteenth century, it had occupied that same part for nearly a thousand years.

It is unfortunate that, although much has been written of the history of British cattle since the middle of the eighteenth century, the period immediately before that is almost without a record. We must therefore, to some extent, fill in this period by reference to what came after. Since the first half of the eighteenth century there have been no more striking phenomena than the advent and progress of two great breeds, 
the Longhorn and the Shorthorn. These in succession swept out many of the old local breeds and occupied their ground instead; and thus, where, say, the Longhorn was found in 1775 , a totally different breed would have been found a hundred years before. What these other breeds were we can infer from the undisplaced breeds around them, and, if possible, find confirmation elsewhere. For example, the Longhorn came into prominence in the English Midlands in the first half of the eighteenth century, and spread gradually southwards as well as in other directions like a rising lake, submerging, as it were, all the existing breeds excepting those that stood high upon the banks around. The southern unsubmerged breeds, with one exception, to which we shall refer later, had many characters in common, but one in particular, that they were all red. Similarly the unsubmerged northern cattle were all black. There is no difficulty in showing that the cattle in Scotland and the North of England were black two centuries ago, for, it will be found from the agricultural and statistical surveys published at the instance of the first Board of Agriculture that they were black at a date still later, while two quotations from Gervaise Markham will show that towards the end of the seventeenth century the black race reached south into England as far as a line drawn approximately from Staffordshire to Yorkshire: "As touching 


\section{EVOLUTION OF BRITISH CATTLE}

the right Breed of Kine through our Nation, it generally affordeth very good ones, yet some Countries so far exceed other countries, as Cheshire, Lancashire, Yorkshire and Derbyshire for black Kine," ${ }^{1}$ and "Those that were bred in York-shire, Darby-shire, Lancashire, and Staffordshire were generally all black." ${ }^{2}$

That the red race possessed the rest of the country till the eighteenth, or at any rate till the seventeenth, century is practically certain, but the proof is less direct than clear. The question is complicated by several factors : by the importation of red and white flecked cattle to Lincoln and some other eastern counties in the sixteenth and seventeenth centuries, by the advent of the new breed-the Longhorns-in the eighteenth century, by the breaking down of the old English system of agriculture which did not encourage the movement of cattle, by the growth of London, and by "the graziers having mixed the cattle more or less in each county." 3 We can look backwards, however, and keep these points in mind in doing so. At the present day we see the south of England encircled by a broken band of red-coloured cattle -the Lincolns, the Norfolks and Suffolks, the Sussex, the South and North Devons, and the Herefords. According to Youatt and Marshall

1 "The English House-Wife," I683.

2 "Cheap and Good Husbandry," 1683, p. 69.

3 "Compleat Body of Husbandry," 1757, vol. iii. p. 36. 
this band was not only continuous a century ago (with one exception), but it was also broader, that is, reaching farther inland. Hale and Markham indicate that it was still broader in their day. Youatt and the writers of the Southern Agricultural Surveys refer again and again to the southern march of the Longhorns and the expulsion of the cattle that were there before them. From these considerations we may say, without doubt, that the red race of cattle, whose representatives to-day are the Lincolns, the Norfolks and Suffolks, the Sussex, the Devons, and the Herefords, were in possession of the southern half of England till towards the close of the eighteenth century. If still further evidence were required, a very interesting statement of Leonard Mascal's might be quoted: "Also for Oxen to labour, the blacke Oxe and the redde Oxe are best, and the browne or greezled Oxe nexte: the white one is worst of all colours." 1 Among cows, "The browne colour mixt with white spots is good, with the redde and the blacke." 1 Remembering that cattle were still valued for draught rather than for milk or beef, we cannot imagine that farmers would be ready to set aside their red or their black cattle for either the red-and-white or the white.

We have thus shown the cattle of the south of England to have been red down to the 1 "Booke of Cattell," I59I. 


\section{EVOLUTION OF BRITISH CATTLE}

eighteenth century. Remembering that before that time cattle were seldom moved from one part to another unless their owners carried them along with them in their migrations, and remembering the history of England at the same time, we may safely say that these cattle were brought to England by the Anglo-Saxons. If still further proof were required, we have only to set a bull of any of the red south of England horned breeds alongside a bull of any of the North Germanic or Danish red Breeds. 


\section{V}

THE NORSE CONTINGENT

$\mathrm{HAD}_{\mathrm{AD}}$ this volume been written a year ago, the present and some of the following chapters would have been written with less confidence than now. Their titles might have been the same, but the efforts of the chapters themselves to live up to their titles might have been somewhat laboured. The polled cattle, for instance, would have been traced to the same origin as now, but the confirmatory evidence afforded by Mendelian researches would have been lacking; and the brindled cattle would have been traced to an origin that would have been entirely wrong.

It is generally believed that the hornless cattle of the British Islands have originated either in reversions or sports which cropped up here and there throughout the country in times gone by. They are believed to have originated in reversions or sports according as hornlessness or hornedness is held to have been the older condition. Darwin favoured the latter view : "It is probable that some breeds, such as the semi-monstrous niata cattle, and some peculiarities 


\section{EVOLUTION OF BRITISH CATTLE}

such as being hornless, etc., have appeared suddenly from what we may call a spontaneous variation," I and "No one can give any explanation-although no doubt there must be a causeof the loss of horns, any more than of the loss of hair, both losses strongly tending to be inherited. It is, I think, possible that the loss of horns has occurred often since cattle were domesticated, though I can call to mind only a case in Paraguay about a century ago." 2

But neither theory will bear much inquiry, for each presumes a phenomenon which has not been seen within what might be called bovine historical time to have been of frequent and widespread occurrence in the earlier days of legend and myth. It is true that many cattle now hornless-and sheep, too, for that matterare descended from ancestors that were horned; but in those cases the horns were removed by crossing with hornless breeds.

Whence, then, came our hornless cattle? That question can only be answered after some consideration of their history and distribution. At the present time there are only three breeds of hornless cattle in Britain; but in the eighteenth century there were hornless breeds in eight or ten places round the coasts of England and

1 "Animals and Plants under Domestication," I868, vol. i. p. 92.

${ }^{2}$ Letter to Messrs. Macdonald and Sinclair, published in their " History of Polled Aberdeen or Angus Cattle," 1882, p. I2. 
Scotland and also in Ireland. It will be necessary to marshal some part of what is known about each of these breeds seriatim.

The Suffolk Duns.-Although Suffolk was renowned for its dairy products four or five centuries ago, we have no earlier description of the Suffolk cow herself than one written in I735. In I 586, Camden wrote that in Suffolk "They also make vast numbers of cheese, which, to the great advantage of the inhabitants, are carried into all parts of England, nay, into Germany also, with France and Spain, as Panteleon Medicus has told us, who scruples not to compare them with those of Placentia both in colour and taste ;" 1 and Speed wrote: "The commodities of this Shire are many and great, whereof the chiefest consist in Corn, in Cattle, Cloth, Pasturage, Sea-Fish, and Fowle; and as Abbo Floriescensis hath depainted, This country is of green and passing fresh hue, pleasantly replenished with Orchards, Gardens, and Groves: thus he described it above six hundred years since, and now we find as he hath said; to which we may add their gain from the Pail ;" ${ }^{2}$ but John Kirby in his "Suffolk Traveller," published in 1735 , describes the cow herself as having "a clean throat, with little dewlap, a snake head, thin and short legs, the ribs springing well from the

1 Gibson's edition, 1750, p. 437.

2 "Theatre of the Empire of Great Britain," 1676, page 33. 


\section{EVOLUTION OF BRITISH CATTLE}

centre of the back, the carcase large, the belly heavy, the back-bone ridged, the chine thin and hollow, the loin narrow, the udder square, large, loose, and creased when empty, the milk veins remarkably large and rising in knotted puffs; and this so general, that I scarcely ever saw a famous milker that did not possess this point, a general habit of leanness, hip bones high and ill covered, and scarcely any part of the carcase so formed and covered as to please an eye that is accustomed to fat beasts of the finer breeds." 1

The colour of the Suffolk cattle may be inferred from a communication of Sir Thomas Beevor's, published in the Bath Society's " Letters and Papers:" "The cows you saw were bred from the polled or horn-less Suffolk dun-coloured cows (than which, for profit, though not for beauty, I think, with the most intelligent $\mathrm{Mr}$. Young, there is not so valuable a breed in England) by a Derbyshire black-and-white bull ${ }^{2}$ given me by my friend, Lord Townshend. This mixture produced their uncommon colour of mouse and white, as well as that shape and make which pleased you, and is so much esteemed by the best judges of cattle; their heads and necks being small, their legs short, carcases large and deep, and loins remarkably

1 Quoted from Youatt's "Cattle," I834, p. 174.

2 A horned breed. 
broad; and being of greater weight in seemingly less compass than any beasts I ever saw ; whether from being without horns, from being constantly kept in shedded yards or houses during the winter, from their nature, or from these causes altogether, they are so tame and docile, that I never knew any mischief done by them to any other animal." I It has been shown recently ${ }^{2}$ that this mouse-coloured dun is the hybrid between black and light dun, and we may infer, therefore, that the colour of the Suffolk breed was light dun. And this inference is confirmed by a remark in Culley's "Observations on Live Stock" that "the Suffolks are almost all light duns." ${ }^{3}$

By Low's time the Suffolks had extended to " Norfolk, Cambridge, and a part of Essex," " but, by crossing with red Norfolk cattle, many of them had changed their colour to yellow, which is the hybrid between red and light dun, and some, by further crossing, had become red. "The prevailing and the best colours are red, red and white, brindled, and a yellowish cream colour." 5 Eventually the Suffolk and Norfolk breeds amalgamated: the former giving up their colour and the latter their horns.

The Northern or Yorkshire Polls.-Few of

1 Vol. iii., second edition, 1788 , p. 280.

2 Proceedings of the Royal Dublin Society, vol. xii., No. 8, "The Colours of Highland Cattle."

${ }^{3}$ Second edition, 1794, p. 66.

4 "Domesticated Animals," p. 322. 5 "Youatt," 1834, p. 175. 


\section{EVOLUTION OF BRITISH CATTLE}

these cattle penetrated far inland. Tuke ${ }^{1}$ informs us that Henry Peirse, of Bedale, had a large herd, and he publishes a representation of a "polled Teeswater cow" belonging to Richard Raisen, Bishopthorpe; but their headquarters were somewhere in the neighbourhood of Holderness. It is doubtful, however, if their numbers ever were large. Lawrence ${ }^{2}$ describes them as having "the same qualities as the short-horned cattle, carrying vast substance, and some I have seen lately are of a great size, although in that particular, they are most conveniently various." Strickland ${ }^{3}$ gives their colour: "This breed is distinctly marked by its colour, being variously blotched with large well-defined patches of deep red or clear black, in some families of dun or mouse-colour on a clean white ground; they are never brindled or mixed, and rarely of one uniform colour."

Durham.-There is evidence of both yellow and dun cattle in Durham in the eighteenth century. Writing in I82 I about a well-known Shorthorn cow which lived about I777, Mr. Thomas Hutchinson says she was "a large yellow cow with some white. .. She might, indeed, have been descended (for anything I know to the contrary) from the old woman's

1 "Agriculture of the North Riding of Yorkshire," I800.

2 "General Treatise on Cattle," etc., 1805, p. 7 I.

3 "Agriculture of the East Riding of Yorkshire," 1812. 
propitious dun cow found at Durham (some time back now), which directed the monks attending the remains of St. Cuthbert to that seat of ease and magnificence." 1

This legendary cow is of unusual interest. Her reward was to have her effigy carved in stone set up in one of the turrets of Durham Cathedral about the year I300. After the Reformation she was the subject of the rhyme that-

"The dun cow's milk

Makes the prebend's wife go in silk,"

which if it be not sufficient to prove that the original cow herself was dun, is evidence that some of her post-Reformation successors were of that colour. That, however, is of small moment compared with the possibility that the model of the effigy may have been hornless. Having become worn and effaced, a new effigy was put up about I778. The original, as will be seen from the illustration below, which is a copy of Grimm's drawing as taken from Hutchinson's " History of Durham," ${ }^{2}$ had no horns. But the Durham people of 1778 had no idea that a Durham cow could ever have been hornless. Weather and time must have made the old cow polled, and the new one therefore was carved to look a Shorthorn!

1 Quoted in Bates's " Thomas Bates and the Kirklevington Shorthorns," I897, p. 45.

2 1785-1794, vol. ii. p. 226. 


\section{EVOLUTION OF BRITISH CATTLE}

But, " the horns were made this time of lead, lest she should ever again be reduced to the condition of a polled beast." 1

The Angus Doddies and the Buchan Humlies.-The hornless cattle of Forfarshire and Aberdeenshire may be considered together because their histories are parallel, and because,

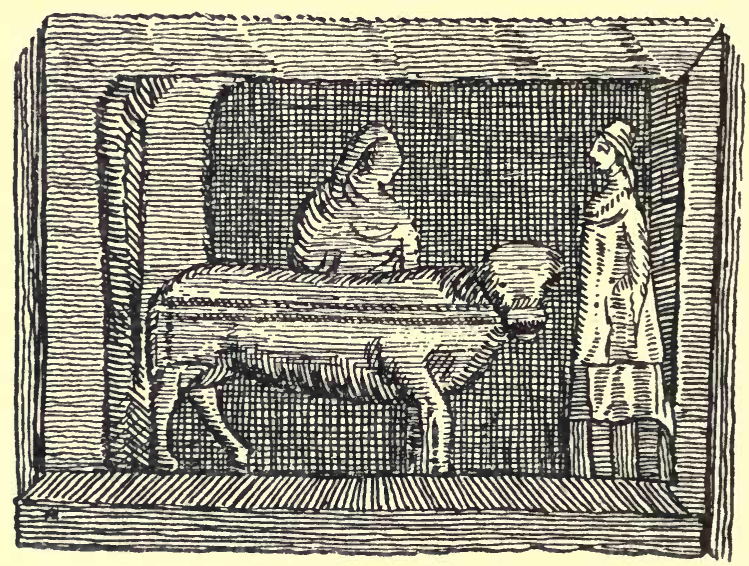

THE DURHAM DUN COW.

[From Hutchinson's "History of Durham."

although there are no definite records to the point, there can be very little doubt but that they are merely separate links in a chain of hornless cattle that occupied the lands on the coast from Forfarshire to Morayshire, if not farther. These cattle are not mentioned by any writer till within a few years of the close of the eighteenth century,

1 "Thomas Bates and the Kirklevington Shorthorns," 1897, p. 46 . 
and it is not likely they were known outside their own territory a hundred years earlier. Early in the eighteenth century there sprang up in England a demand for hornless cattle which was responded to first in Galloway, and considerably later in the north-eastern counties. The result was that breeders elected to breed from hornless cattle; and hornlessness, which had hitherto been practically confined to the country near the coast, moved farther and farther inland. By Youatt's time (1834) the horned and the hornless cattle were almost numerically equal in the interior of the north-eastern counties, while the hornless ones were still in the majority on the coast. A quarter of a century later the horns had been almost entirely removed from the inland black cattle.

Unfortunately, we have no contemporary description of the original east-coast hornless cattle; but, from Youatt's and other notes on the colours of Forfarshire and Aberdeenshire cattle, and from a description of Aberdeenshire cattle, as they appeared about 1830, written by an Aberdeenshire farmer for Messrs. Macdonald and Sinclair, their characters can be inferred.

It must be remembered that, after the middle of the eighteenth century, many large southern cattle were introduced to the north-eastern counties. At first, these were chiefly Fifeshire 


\section{EVOLUTION OF BRITISH CATTLE}

cattle, with a smaller number of Longhorns and Longhorn grades or crosses. Latterly, Shorthorns predominated. Consequently we must look for variations in size as a result of crossing with the imported stock. At the same time we must look for several new colours in addition to the original black. Mr. Forbes, the Aberdeenshire farmer referred to, writes thus: "The cattle in Buchan $^{1}$ about half a century ago and earlier might be said to have consisted of horned and polled black cattle in about equal proportions. The polled cattle were of two classes, one large and another small. I knew the small kind well. They were rather puny creatures, always thin in flesh, and very badly used. They were preeminently the crofter's cow, as they were able to live through the winter on the straw of oats and bere, and water, if necessary. Of the larger portion of the cattle, about one-half were jet black, excepting the udder, which was usually white. They could not stand starvation so well as the small polls, but with better treatment they gave a heavier yield of milk. When creamed, however, their milk was thinner than that from the small cows." 2

As to the colours of the Forfarshire polled cattle, Youatt writes: "The greater part of them are black, or with a few white spots. The next

1 That is, East Aberdeenshire.

2 "History of Polled Aberdeen or Angus Cattle," p. 72. 
general colour is yellow, comprehending the brindled, dark red and silver-coloured yellow." 1 Among Forfarshire horned cattle " the prevailing colour is black, but with more admixture of other tints: some have white spots on the forehead, and white on the flanks and belly. There are more brindled cattle than in Aberdeen ; some are dark red, and others of a silver yellow or dun. A few are black with white hairs intermixed; and occasionally a beast is seen that is altogether white, with the exception of a few black hairs about the head." ${ }^{2}$ Youatt makes no kind of reference to the Aberdeenshire polled cattle, but of the horned ones he writes, "The colour is usually black, but sometimes brindled." ${ }^{3}$ Macdonald and Sinclair tell us that "Formerly, both in Angus and Aberdeen, the breed ${ }^{4}$ embraced a variety of colours as well as difference in size. Black, with some white spots on the underline, was the prevailing colour. Some were brindleddark red and black stripes alternately; others were red; others brown; and a few what Youatt called 'silver-coloured yellow."' 5 An early nineteenth-century Banffshire writer tells us that, with the dealers who came to Rathven for cattle, "The favourite colour is pure black. The brindled ranks next in esteem, and the

1 "Cattle," p. 167.

3 Ibid., p. ro6.

2 Ibid., p. II 4.

5 "Polled Aberdeen and Angus Cattle," p. 76. 


\section{EVOLUTION OF BRITISH CATTLE}

dun is not disliked. Pure white or streaked are counted inferior." 1

Here, in a few words, we have the early history of the modern Aberdeen-Angus breed. Scarcely had the inland horned black cattle begun to unite with the hornless coast cattle when they resolved to take in partners from the south. In course of time the amalgamation resulted in a breed with characters derived from several sources : blackness from the native horned cattle, hornlessness from the coast cattle, and size from the cattle from the south. Some of the characters brought in, and other characters, which appeared during the process, were eventually eliminated. Here we are only concerned with the colours. We know those of the native horned cattle and of the cattle brought in from the south, and we also know the new colours that could have arisen from the mixing of these. Altogether they were : black from the native and the Fifeshire cattle; red, brindled, and white marks above and below from the Longhorns and their crosses; and red, red and white, roan, white, and blue roan from the Shorthorns. Brown was, perhaps, in the country before the southern cattle came in. If not, it came in with the Longhorns. But other colours are reported to have appeared by Youatt and the other writers quoted. There are yellow,

1 "Transactions of the Highland and Agricultural Society of Scotland for 1906," p. 204. 
"silver-coloured yellow," and dun : colours which could not have arisen otherwise than by contact with light dun cattle. That being so, there can be no other conclusion than that the colour of the east-coast partners was light dun. It could also be shown, although there is no need here, that some of the characters Mr. Forbes referred to, such as small, puny, thin-fleshed, and producers of rich milk, came originally from the hornless cattle, which, upon the whole, turn out to have been wonderfully like the Suffolks.

The Sutherland Polls. - The Sutherland polled cattle are long extinct, and it is only from an almost casual remark of Pennant's that we know they ever existed. "Sutherland is a country abounding in cattle, and sends out annually 2500 head, which sold about this time (lean) from $£_{2}$ Ios. to $£_{3}$ per head. These are frequently without horns, and both they and the horses are very small." ${ }^{1}$ According to Youatt, the native cattle of Sutherland were very small : "much smaller than those of Caithness." ${ }^{2}$ Their colour is not mentioned, but a correspondent of Youatt's wrote him that the cattle in the neighbouring county, Ross, "are of all colours, but black and brindled predominate." ${ }^{3}$

The Skye Polls.-We know that at one time there were polled cattle in Skye just as we know

1 "Tour in Scotland," third edition, I774, vol. i. p. I70.

2 "Cattle," p. 93.

3 Ibid., p. 97. 


\section{EVOLUTION OF BRITISH CATTLE}

there were polled cattle in Sutherland: only this time our authority is none less than Dr. Samuel Johnson himself, who made his famous tour to the Highlands in I773: "The cattle of Sky are not so small as is commonly believed. . . Of their black cattle some are without horns, called by the Scots humble cows, as we call a bee an humble bee, that wants a sting. Whether the difference be specifick, or accidental, though we inquired with great diligence, we could not be informed. We are not very sure that the bull is ever without horns, ${ }^{1}$ though we have been told that such bulls there are. What is produced by putting a horned and an unhorned male and female together, no man has ever tried that thought the result worthy of observation." 2 The colour of the cattle in Skye in Johnson's time is not recorded, but dun and yellow, the colours produced by crossing black and red with light dun are common among Highland cattle; and light dun itself is not unusual. At the present day, light dun and dun occur more frequently among the Highlanders of Skye and the neighbouring islands than among those of the mainland; and an inspection of the foundation entries in the "Highland Herd Book" indicates that at one time these colours were of more frequent

1 Just as the Aberdeenshire men, who desired hornless calves, used hornless bulls, the Skye men, who desired horned calves, used horned bulls.

2 Johnson's "Collected Works," Dublin, 1793, vol. iv. p. 479. 
occurrence than now. MacGillivray, in his "Report on the Present State of the Outer Hebrides," published in 1834, writes that "the common colours are black, red, brown or brandered, that is a mixture of red and brown in stripes-brindled. A whitish dun ${ }^{1}$ colour is also pretty frequently seen." ${ }^{2}$

The Galloways. - The history of the Galloways is very similar to that of the Aberdeen-Angus, excepting that they felt and responded sooner to the English demand for hornless cattle. There is no description of the original hornless cattle of Galloway, but the presence of dun among their descendants, even down to the present day, connects them with the other hornless cattle round the British coasts. According to Youatt, the majority of the cattle in Galloway were horned in the middle of the eighteenth century; but in Culley's time the horned ones were extinct : the Galloways' " most essential difference from every other breed is in having no horns at all." ${ }^{3}$ In this respect they were at least half a century ahead of the Aberdeen-Angus.

The Devon Natts. - The hornless Devon cattle have been extinct for about a century ; and, although there are several references to them, there is no full description. Their territory was

1 That is apparently what is now called light dun.

2 "Prize Essays and Transactions of the Highland Society."

3 "Observations upon Live Stock," second edition, I794, p. 69. 


\section{EVOLUTION OF BRITISH CATTLE}

about Barnstaple on the north coast : the district in which the modern North Devon breed originated. The polled Devons were described to Lawrence as " coloured, middle-sized, thick-set, and apt to make fat, but coarser than the true-bred Devon." Their colour is not recorded, but, in the "Annals of Agriculture" for I792, a writer called Treby mentions both yellow and hornless cattle in South Devon. ${ }^{2}$

The Somerset Polls. - These are also extinct. Low wrote of them: "The Sheeted Breed of Somerset ... has existed in the same parts of of England from time immemorial. The red colour of the hair has a slight yellow tinge, and the white colour passes like a sheet over the body. The individuals are sometimes horned, but more frequently they are hornless." 3 There is a portrait of two sheeted Somerset cows, a horned and a hornless, in the Low collection of paintings in Edinburgh University.

The Irish Maoiles.-Hornless cattle of the old Irish race are found here and there chiefly in the west and in the north: from the level of Roscommon to Donegal and Antrim. Their numbers are now small, and there being no

1 "General Treatise on Cattle," etc., 1805, p. 7 I.

2 The presence of these hornless cattle at Barnstaple raises several unusually interesting questions, viz. Did they impart their shortness of leg to the North Devon breed, and did the short legs of the Dexter which came from Devon cattle come originally from Scandinavians?

3 "Domesticated Animals," p. 350. 
systematic attempt to breed them pure unless by a very few owners of small herds, their extinction seems only a matter of not very many years. At the present day the Irish Maoiles are generally full-sized cattle. There are many colours among them, viz. black, red, brindled, flecked, yellow, and dun. Yellow is generally held to be the proper colour. Here again we get back to light dun, the original colour of all the other hornless breeds; and one of the breeders writes that he once owned a "steel gray Mulline." The Irish Maoiles have also some other characters common to some of the other breeds. They are usually good milkers, and are sought after on this account; many of them give very rich milk; they are often short-legged, big bodied, narrow backed, with sickle-shaped hocks that brush each other at every step.

Looking back again at these descriptions of the hornless British breeds, there can be no other conclusion than that they did not originate in separate and independent reversions or variations, but that they were all descended from the same race, which was entirely different from the others in Britain. It was hornless, of course, it was light dun in colour, and small in size; it had a long "snake" head, narrow chine and loins, a deep body, short thin legs, sickle-shaped hocks, and it gave a good yield of milk richer than usual. The fact that the hornless breeds were located 


\section{EVOLUTION OF BRITISH CATTLE}

in maritime districts, and that these lay right in the tracks of the Norsemen, immediately suggests that the hornless race was of Scandinavian origin. In support of this suggestion it can be shown that the hornless cattle came to Britain at the same time as the Norsemen, that similar cattle were taken to other places where the Norsemen settled, and that the same race still exists in Europe from Norway to Northern Russia.

Although the hornless breeds are not mentioned by any writer till the eighteenth century, they were in Britain long before that time. In a legal document, dated I523- "Instrumentum sasine in favorem Johannis Cumying "-it is recorded that the lands of Culter in Aberdeenshire passed from one man's possession to another's by the new owner receiving not the usual token, a handful of earth and a stone, but " unum bovem nigrum hommyll appretiatum ad quadragintas solidos et octo denarios monete Scotie : " - a black hummle, i.e. humble, i.e. hornless ox, valued at 40s. $8 d$. Scots. The Norsemen themselves have left evidence of the existence of hornless cattle in the North East of Scotland in their own time. It consists of a number of stone slabs bearing chiselled-out figures of bulls dug up on the shores of the Moray Firth chiefly at Burghead, in Morayshire, which was a Norse or Danish stronghold.

1 The Spalding Club's "Collections for a History of the Shires of Aberdeen and Banff," vol. iii. p. 344. 
The figures show two kinds of bulls, a horned and a hornless. The following illustrations of
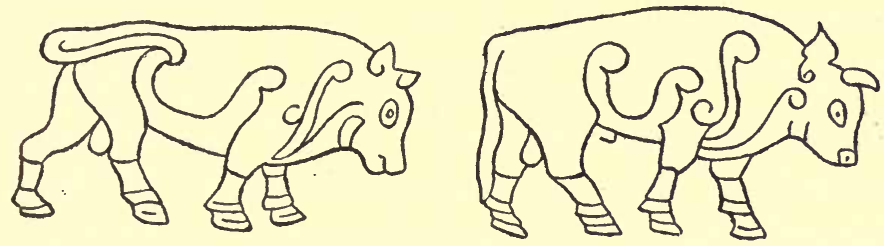

BURGHEAD BULLS.

[From "The Sculptured Stones of Scotland."

them are copied from "The Sculptured Stones of Scotland." ${ }^{1}$ And there is evidence of hornless cattle in Ireland as early as the ninth or the tenth century. In a crannoge near Dunshaughlin, about seventeen miles north-west of Dublin, a considerable number of hornless and other skulls was unearthed in the middle of last century. Some of these are now in the National Museum in Dublin, and one of them is figured here. Sir

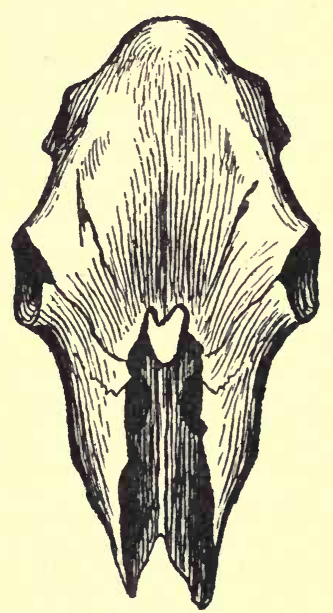

HORNLESS SKULL, FROM THE DUNSHAUGHLIN CRANNOGE.

[Drawn from a specimen in the Dublin National Museum. William Wilde was able to fix the crannoge's range of date at from 848 to 933 A.D. 


\section{EVOLUTION OF BRITISH CATTLE}

But these facts, although they are suggestive, do not necessarily confine the arrival of the hornless cattle to the times of the Norse invasions. That, however, can be done by other considerations. By their geographical position, wedged in, as it were, between the red Anglo-Saxon cattle and the sea, the arrival of the Suffolk breed cannot be placed earlier than the very end of the Anglo-Saxon invasion. The same might also be said about the Devon and Yorkshire polls. And the fact that archæologists, although they have found other skulls, have failed to find hornless skulls either of Roman or Anglo-Saxon date in East Anglia or any other hornless district, points to the same conclusion.

The latest date for the arrival of the hornless cattle in Britain can also be fixed. It is somewhere before the Norman Conquest. In previous chapters of this book it was shown that there was no general migration of cattle to Britain from Anglo-Saxon times till the Dutch importations of the seventeenth and eighteenth centuries, and that these were horned, not hornless cattle. It was also shown that, in earlier times at any rate, cattle migrations were coincident upon the migrations of their owners. The only two sets of men who could have brought in the hornless cattle were therefore the Norsemen and the Normans. The latter we know to have consisted entirely of the nobility and 
their military followers, who, when they had ousted the English landlords, put themselves in their stead, and therefore had no need to bring over cattle from their Norman lands. Besides, the hornless cattle were found chiefly in parts of Scotland and Ireland where the Normans did not penetrate. We are therefore driven to the conclusion that the importers of the hornless cattle were the Norsemen. But, if further proof were required, there are still the facts that cattle of the same race were taken to other Norse settlements, and that others still remain in Norway. These cattle may be identified, not only by their hornlessness but also by their colour, size, and shape. In most places, some of their original characters have been lost by crossing with other cattle. But if, in likely places, we find cattle bearing some of the original Norse characters, the presumption that they are of Norse descent is clear: more especially as some of the original characters were peculiar to the Norse cattle only. Thus the cattle of the Channel Islands can be identified as of the same race by the presence of light dun-called silver grey and so on-and yellow; by their shapes; and also by the quality of their milk. There are still dun-coloured cattle in Orkney and Shetland, and fifty years ago there were many more, especially in Shetland. Low was absolutely clear that they were of Scandinavian origin, after 


\section{EVOLUTION OF BRITISH CATTLE}

having fully compared them with the cattle of Norway. The cattle of Iceland, which are undoubtedly Norse, were thus described by Uno von Triol in 1780: "Their beeves are not large, but very fat and good. It has been reported by some, though without foundation, that there are none without horns: it is true, however, that they seldom have any." ${ }^{1}$ It might also be remarked that the old Caithness cattle bore some of the characters of the hornless cattle: "The chest was small, and the ribs flat, and the back thin; there was not room for the back to beat, nor the lungs to play." 2

Perhaps a still more striking link is the recent discovery in some earthen mounds in North Holland of skulls similar to those found in Ireland. In dealing with these skulls in Cultura for 1908, the magazine of the old students of the Royal Agricultural College, at Wageningen, Professor Broekema points out that some Scandinavian bracelets and cloak-pins were found in the same mounds.

There are small bunches of hornless cattle here and there in other parts of Europe; but, according to Wilckens, " in Northern Europe, in North Russia, Finnland, Lappland, Sweden, Jemtland, Norway and

1 "Letters from Iceland," 1780, p. 132.

2 Youatt's "Cattle," p. 88.

3 "Grundzüge der Naturgeschichte der Haustiere," p. 308. 


\section{THE NORSE CONTINGENT}

Iceland." Mittendorff, ${ }^{1}$ maintains that they are the lineal descendants of the hornless cattle of the Ancient Scythians, mentioned by Herodotus, and that they wandered north from the south of modern Russia, and then westwards into Scandinavia. If this be so, then it may be possible some day to trace them still farther back either into Asia or to the hornless cattle of the early Egyptians. For the present, however, we are concerned with them in Scandinavia, and two quotations will be sufficient to show that the hornless race makes itself manifest there precisely as it has done in Britian. The first quotation is from a letter received from Professor Isaachsen of Aas, in Norway: "As to our cattle up to the year I600, we know very little. But in these days, like in ours, there were several distinct breeds in our country, and probably they have not changed their characteristics very much. Especially in the western and south-western parts of Norway, the so-called 'Westland,' from which part of the country the first settlers are supposed to have come to your country, the breed is partly horned, partly polled, about half the animals being polled, I think. The colour of the breed is either black, dun, red, or grey, whole-coloured or with small or large white marks or spots. In the south-eastern parts of

1 See Landwirtschaftliche Jahrbïcher, vol. xvii., 1888, pp. 299, 300. 


\section{EVOLUTION OF BRITISH CATTLE}

Norway, especially in Akershus and Smaalenene, the indigenous breed is constantly red and polled. In Esterdalen and Gudbrandsdalen, the two large eastern valleys of the country, the native breed is black or dun, in some cases red, most of the individuals being horned: only a few are polled. The breed in the western parts of Norway we suppose to be the most ancient, or one of the most ancient, in our country."

The other quotation, and the following illustration of a cow of the Swedish fell or mountain (Fjall) race are taken from Sundbärg's "Sweden, its Population and its Industries," published in 1904. "The History of the cattle in our country presents a good many vicissitudes. The Law of Uppland, A.D. I 296, describes Swedish cattle as being small, hornless, white or whitish grey, often with dark spots. The Alpine breed in Northern Sweden is so still, a race we have every reason to consider as being the oldest in the country."

There is some doubt as to whether the colour here called "whitish grey" is the same as our light dun. Samples of hair which have been procured through the kindness of several correspondents in Sweden are some white and some light dun.

It ought to be mentioned that several of the British "wild" white herds are, or were, hornless. Their unfailing white colour suggests, however, 
that they are not of the Norse race, and the recent discovery of hornless skulls at Newstead, an old Roman centre in Berwickshire, and

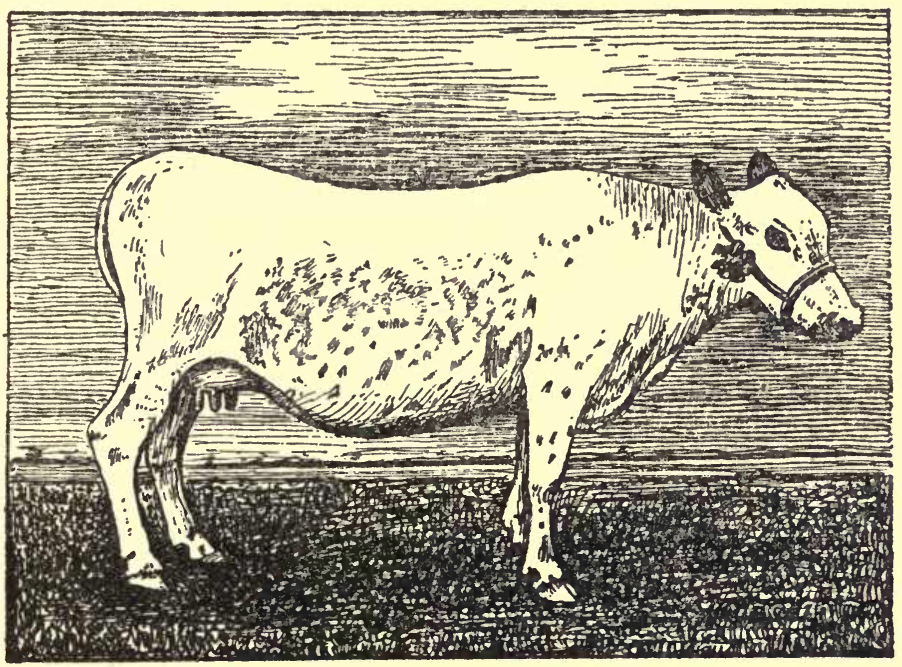

SWEDISH FJÅL COW.

[From Sundbärg's "Sweden."

referred to by Professor Cossar Ewart in the article "Cattle" in the Standard Cyclopadia of Agriculture, points to their having come from the south of Europe with the Romans. 


\section{VI}

\section{THE DUTCH INVASION}

Although it was not till the seventeenth and eighteenth centuries that what we might call the "Dutch Invasion" took place, the tracks of the cattle brought in from the Low Countries at that time are only a little clearer than those of the Scandinavian cattle that came across the North Sea seven or eight hundred years before. One reason for this is that there was no great human migration to correspond; while another is that, misled by the great change the Dutch cattle induced upon the cattle of Britain, we look for the importations of enormous numbers: forgetting that such are not required if the imported animals and their progeny were thought much more worthy than those whose territory they invaded. The recent increase of Shorthorns and Herefords outside Britain might be quoted as cases in point.

In Britain there were incentives to the importation of foreign stock that had never existed before. During the sixteenth century, through political and other interests, England was drawn 
further and further away from France and Spain, and closer and closer to Holland and Northern Germany. Elizabeth came to the throne in ${ }^{5} 55^{8}$; and the Netherlands revolted against Spain in 1572 .

"Volunteers stole across the channel in increasing numbers to the aid of the Dutch, till the five hundred Englishmen who fought in the beginning of the struggle rose to a brigade of five thousand, whose bravery turned one of the most critical battles of the war." 1 In I 585 "Lord Leicester was hurried to the Flemish Coast with 8000 men." 2

Englishmen renewed their acquaintance with Holland and Western Germany during the Thirty Years' War, begun in 1618; while during the sixteenth and seventeenth centuries, persecuted Flemings and Huguenots came flocking to Britain.

Before their revolt, the Low Countries had long been in advance of the rest of Europe in agriculture and industry and, after the emancipation of Holland, this advance was far more than maintained, not only in Holland, but also in the neighbouring States still under the rule of Spain.

Dutch and other foreign agricultural books were translated into English, and English writers

1 J. R. Green's "Short History of the English People," illustrated edition, p. 828 .

2 Ibid., p. 832. 


\section{EVOLUTION OF BRITISH CATTLE}

described continental crops and farming methods. Leonard Mascal, who is asserted to have introduced pippin apples and carp, and who had travelled on the Continent, published " "A Booke of the Arte and manner, how to plant and graffe all sortes of Trees by one of the Abbey of St. Vincent in France, with an addition of certain Dutch practices," in I572, "The Husbandrie, ordering and Government of Poultrie," in I $58 \mathrm{I}$, and "The Government of Cattel," in I596, Heresbachius's "Foure Books of Husbandry, Newely Englished, and increased by Barnabe Googe," was published in I577; Sir Hugh Plat's "Jewel House of Art and Nature," in which a great knowledge of the Low Countries is shown, was published in I594; Bishop Dubravius's (of Olmutz) "New Booke of Good Husbandry," was published in English in I599; Sir Cornelius Vermuïden, a Dutchman, published his "Discourses touching the Drayning of the Great Fenns," in 1642; and Hartlib published Sir Richard Weston's "Discourse of Husbandry used in Brabant and Flanders," in I645, "The Legacy ; or, an Enlargement of the Discourse," in $165 \mathrm{I}$, and the "Appendix to the Legacy," in the same year.

Thus, through books and returning soldiers and travellers, a knowledge of the agriculture of the Low Countries was filtering through to English 1 McDonald's "Agricultural Writers," 1908, p. 42. 


\section{THE DUTCH INVASION}

farmers just at the time when it was likely to have fullest effect. The feudal system, and the cast-iron method of agriculture by which it was accompanied, had already begun to break down. The village, with its three fields and its threecourse rotation of wheat the first year; beans, peas, or other grain the second; and fallow the third, still prevailed, but rents were now usually paid in money instead of in service and kind. Landowners had become business men rather than feudal chiefs, and, in consequence, much of the land that had formerly been forest and waste was parcelled out in large blocks to be farmed by the landowners themselves or rented to farmers. Fields were enclosed both for tillage and grazing, and the economy of this system over the old "mingle-mangle" of the village system, both as regards crops and stock, was soon realised. Formerly, no man could adopt new crops or a new rotation, because his fellow-villagers and the three-field system were both against it ; formerly, no man could improve his stock unless the rest of the villagers did the same, because the male breeding animals were used in common, and the female stock must all be grazed together. Now the "champaign" farmer could grow the crops that brought most profit, adopt an independent rotation, and select and improve his live stock as he had a mind.

Thus, many British farmers were free to take 


\section{EVOLUTION OF BRITISH CATTLE}

advantage of the example and advance of the Low Countries. The change could not come all at once, however, but it was begun about 1644 through the introduction of turnips and red clover to Kent by Sir Richard Weston, who had been educated in the Low Countries, and who, in later life, passed some years of exile there $;^{1}$ and it was accelerated by the work of Jethro Tull and Lord Townshend early in the following century. And just as better crops and better farming were introduced by Sir Richard Weston and others, so also were better stock imported by proprietors and farmers who wished to improve their own and the cattle of the country.

It will be noticed that, so far, the original British cattle and all the intruding races were whole coloured : the Celtic cattle were black, the Roman white, the Anglo-Saxon red, and the Scandinavian light dun. The cattle now to be imported were chiefly of broken colours. The date of their first arrival cannot now be fixed, but the will of John Percy, of Haram, near Helmsley, in Yorkshire, suggests that it may have been as early as I 400 : "To my son John I bequeath two stots with short horns; to John Webster a small horned stot; to John Belby a cow with a white leske; to my son a heifer with a white head." ${ }^{2}$

1 "Dictionary of National Biography."

2 Bates's "Thomas Bates and the Kirklevington Shorthorns," 1897, p. 23. 


\section{THE DUTCH INVASION}

But, if John Percy's white-headed heifer was descended from imported cattle, the importations must either have been very few, or in poor demand, for there is no indication that the Yorkshire cattle, unless those in the parks and their tame cousins in the possession of one or two families, were otherwise than black till three centuries later. Besides, it was in Lincolnshire, to which Dutchmen came to drain the fens, that the Dutch cattle are first reported to have gained a footing. In ${ }^{168} 3$ Gervaise Markham writes ${ }^{1}$ : "As touching the right Breed of Kine through our Nation, it generally affordeth very good ones, yet some Countries do far exceed other Countries, as Cheshire, Lancashire, Yorkshire, and Derbyshire, for black Kine; Gloucestershire, Somersetshire, and some part of Wiltshire for red Kine ; and Lincolnshire for pide Kine."

Thirty-three years later Mortimer ${ }^{2}$ tells us where these Lincolnshire cattle had come from, and also that cattle of the same kind had been imported to Kent: "But the best sort of Cows for the Pail, only that they are tender and need very good keeping, are the long-legg'd, shorthorn'd Cow of the Dutch-breed, which is to be had in some places of Lincolnshire, but most used in Kent."

Still another forty years later, $\mathrm{Hale}^{3}$ refers to

1 "The English House-Wife."

2 "The Whole Art of Husbandry," 1716, p. 227.

3 "Compleat Body of Husbandry," vol. iii. p. 35. 


\section{EVOLUTION OF BRITISH CATTLE}

the same race of cattle several times, and shows that the native and imported races had already begun to mix: "The Yorkshire oxen are, in general, black all over, and they are very large, firm, and valuable Kind in every respect. There are none that exceed them for Labour and few feed like them. The Oxen of Staffordshire, and many of the neighbouring Counties, are also of this kind. The Oxen of Lincolnshire are in general red-and-white: they are very bulky, and equal to any in Value. The Oxen of Somersetshire, and some of the adjoining Counties, are naturally red. They are also a very fine, large, and valuable Breed. . . The reader is not to suppose from what is here said, that all the Oxen of Yorkshire are black, all those of Gloucestershire and Somersetshire, red; or all the Lincolnshire oxen pyed. These are the genuine and proper breed of each of those several Counties, but the graziers have mixed them more or less in each County."

Again, "The Welch and Scotch Cows will do upon the poorest Pastures. They will suit some who cannot rise to the better kinds ... but the fine Kinds are the Dutch and Alderney cows, these are very like one another in Shape, and in their Goodness, but the Alderney Cow is preferable, because she is hardier.

"The fine Dutch Breed have long legs, short Horns, and a full Body. They are to be had in Kent and Sussex, and some other Places where 
they are still carefully kept up without Mixture in Colour, and where they will yield two gallons at a milking; but in order to this they require great Attendance, and the best of Food. The Alderney cow is like the Dutch in the Shortness of her Horns, but she is somewhat stronger built, and is not quite so tender."

One more extract will bring us down to comparatively recent times, and will show how the Dutch cattle continued to be imported, and how their territory in the east of England extended. It is from "Observations on Live Stock," first published in 1786, by George Culley, a Durham man, who was first a pupil with Bakewell and afterwards a farmer in Northumberland.

Of "the shorthorned or Dutch kind," Culley writes: "Their colours are much varied; but the generality are red-and-white mixed, or what the breeders call flecked; and, when properly mixed, is a very agreeable colour.

"There are many reasons for thinking this breed has been imported from the ContinentFirst, because they are still in many places called the Dutch breed. Secondly, because we find very few of these cattle any where in this island, except along the eastern coast, facing those parts of the Continent where the same kind of cattle are still bred, and reaching from the southern extremity of Lincolnshire to the borders of Scotland. The longhorns and these have met upon the 


\section{EVOLUTION OF BRITISH CATTLE}

mountains which separate Yorkshire from Lancashire, etc., and, by crossing, have produced a mixed breed called the Half longhorns; a very heavy, strong, and not unuseful kind of cattle; but we do not find that the one kind have spread further West, or the others further East. But, thirdly, I remember ${ }^{1}$ a gentleman of the county of Durham (Mr. Michael Dobinson), who went in the early part of his life into Holland in order to buy bulls; those he bought were of much service in improving the breed; and this $\mathrm{Mr}$. Dobinson and neighbours, even in my day, were noted for having the best breed of short-horned cattle, and sold their bulls and heifers for great prices.

"But afterwards, some other persons of less knowledge going over, brought home some bulls, that in all probability introduced along that coast the disagreeable kind of cattle, well known to breeders adjoining the river Tees, by the appellation of lyery, or double-lyered; that is, blackfleshed. . . .

"The breed, like most others, is better and worse in different districts ; not so much, I apprehend, from the good or bad quality of the land, as from a want of attention in the breeders. In Lincolnshire (which is the farthest south that we meet with any number of this kind of cattle)

1 Culley was born in I730. See Sinclair's "History of Shorthorn Cattle," p. I7. 
they are, in general, more subject to lyer or black flesh, than those bred farther North; and in that rich part of Yorkshire called Holderness, they are much the same as those south of the Humber, of which we have been speaking. It is probable that they had either stuck more to the lyery black-beefed kind, than their more northern neighbours, at that unfortunate period when they were imported from the Continent, or that the latter had seen their error. But from whatever cause this happened, it is a fact, that as soon as we cross the Yorkshire Wolds, northward, we find this breed alter for the better; they become finer in the bone, in the carcase, and, in a great measure, free from that disagreeable lyery sort which has brought such an odium upon this, perhaps, most valuable breed. When you reach that fine country on both sides of the River Tees, you are then in the centre of this breed of cattle; a country that has been long eminent for good stock of all kinds; the country where the Dobinsons first raised a spirit of emulation amongst the breeders, which is still kept up by Mr. Hill, the Mr. Charges, the Mr. Collins, Mr. Maynard, etc." 1

It is unnecessary to make more or later quotations to show that these east-country English cattle came from the opposite shores of the German Ocean. Documentary evidence as to

${ }^{1}$ Quoted from the second edition, 1794, p. 40. 


\section{EVOLUTION OF BRITISH CATTLE}

their progress farther westward is unusually scanty. Indeed, were it not that the cattle themselves carried evidence of their origin wherever they went, their westward march in England might still remain not proven. But, early in the eighteenth century, characters appear among the cattle in some of the midland counties and in the west and north-west which were previously unknown in those parts of England, but were well known in Holland and Flanders. These are increase in size and the markings which are still peculiar to the Herefords and the Longhorns. These two breeds and the Shorthorns were almost the only large cattle in Britain till the nineteenth century was well through.

Hale tells us that, in his day, 1757, the graziers had already mixed the breeds "more or less in each country," while Culley's remark that " a very heavy strong" breed had been raised "upon the mountains which separate Yorkshire from Lancashire" by crossing the Yorkshire and Lancashire cattle is in itself evidence that the large West European cattle had reached Lancashire long before Culley's time. Still better evidence is to be found in some of the old "Agricultural Surveys," in which the authors, not knowing of the banishment of the older cattle, speak of these great cattle that were Flemish or Dutch in appearance, size, and markings as "native," "indigenous," and so on. In Pitt's 
"Survey of Staffordshire," for instance, some enormous cattle with white faces and white backs and under-lines, are figured as old Staffordshire cattle. But perhaps the most valuable statement of all is that to be found about Lord Scudamore in Cooke's continuation to Duncumb's "Collections towards the History and Antiquities of the County of Hereford." Scudamore, whose family had been famous for generations for their horsemanship and breed of horses, ${ }^{1}$ was a friend of George Villiers, Duke of Buckingham, and, when the latter was assassinated in 1628 , retired to his estate at Holme Lacy and devoted himself to agricultural improvements. His retirement was twice interrupted, first in 1634 by his becoming Ambassador in Paris for four years, and again in 1643 by his being imprisoned for three years for rebellion. He is credited with having introduced the red-streak apple, and so turned Hereford into a county of orchards and cider; and also with having introduced the cattle from which the present Herefords are descended. Cooke's statement is as follows : "Francis Hereford, son of Roger Hereford, a merchant of Dunkirk, married in the Netherlands and left several children. Roger Hereford, a younger son, also a merchant at Dunkirk, becoming a naturalised subject, was on three occasions chief magistrate of that city. These gentlemen are traditionally credited with

${ }^{1}$ See "Dictionary of National Biography." 


\section{EVOLUTION OF BRITISH CATTLE}

having procured in Flanders, for Lord Scudamore, the cattle from which the celebrated herds of the county are descended." ${ }^{1}$ It is a pity this statement conveys no information which would indicate how far Lord Scudamore's cattle were responsible for the markings of the modern Herefords, or for those of the finch-backed cattle that were once so numerous in their neighbourhood. It would also be interesting to know the route by which Lord Scudamore's cattle were sent from Flanders.

1 Cooke, p. 73. 


\section{VII}

\section{THE FOUNDLINGS}

So far we have dealt with the different races of cattle that have come to Britain according to the order of their arrival. Now we have to deal with a race whose presence in Britain is a puzzle; for not only must we confess ignorance as to the date of its arrival, but even doubt as to whether it ever arrived at all. At the present day, animals of this race have an unpleasant habit of turning up unasked in several breeds, most notably among Highlanders and Longhorns. Among Highlanders these unwelcome visitors are almost black in colour with a brownish stripe along the back and a ring of similar colour round the muzzle. They are seldom retained for breeding purposes, unless they are unusually good heifers: in which cases they are registered as some shade of brown-in Gaelic donn-sometimes as a brindle.

In former times there were far more of these blackish-brown cattle in the Highlands than now. Indeed, early in the nineteenth century they were found wherever the old Celtic black cattle were 


\section{EVOLUTION OF BRITISH CATTLE}

found in Scotland, the north of England, Wales, and Ireland-but, since the establishment of pure breeds, and perhaps before that, they have gradually disappeared : the Highland breed being the last of the Celtic breeds to give them a lodging. There are still a few among the nonpedigreed Irish black cattle, but very few in the territories of the Welsh, the Galloways, or the Aberdeen-Angus.

Being registered among Highlanders, it is among them we must first look for the link that may connect these cattle with other breeds and perhaps with the race to which they belong; and an examination of the Highland Herd-Book shows that the Highland brindles have been produced by crossing this blackish-brown race with the other three fundamental colours belonging to the breed, viz. black, red, and light dun (sometimes in other breeds described by such words as "grey" and "silver grey").

Is there any other British breed of cattle in which brindles are known, and, if so, what is their origin? 'There is one breed, the Longhorns, and the Longhorn brindles also revert back to a similar ancestral race, which is described, however, not as brown or donn, but as mulberry or plum coloured. Are there any other cattle in which these same phenomena can be traced? There is one other breed, almost at Britain's doors, in which this same brown, or 
plum, or mulberry colour is quite common, namely, the Jersey; and when the Jersey cattle of this colour are crossed with red or black cattle, the brindles of the Longhorns and Highlanders are produced. ${ }^{1}$ And from Jersey it is but a step to France and another to Switzerland for cattle of the same colour.

These four sets of cattle-the Highlanders, Longhorns, Jerseys, and Swiss-being thus connected, the question next arising is, when and how did these blackish-brown cattle come to Britain? There is no clear mention of them till about a hundred years ago; but even then they were numerous. During the eighteenth century the cattle by which it was most sought to improve all others were the Longhorns. They were carried in great numbers to Ireland, to other parts of England and Wales, to Scotland, and even to the Orkneys. Many of them, as we know, were brindled, and when their brindled descendants were bred together the ancestral blackish-brown was bound to appear. Hence the suggestion in the beginning of this chapter that we do not know that the blackish-brown cattle themselves came to Britain. Their parents may have come.

But where did the Longhorns get their brindled colour? They originated in that part of England

1 Cross-breds between Sussex and Devon bulls and Jersey cows almost invariably come brindle. C. J. Davies in Live Stock Fournal, January I, 1909 . 


\section{EVOLUTION OF BRITISH CATTLE}

where the Celtic, the Roman, the Anglo-Saxon, and the Dutch races met. The Roman and the Anglo-Saxon races were white and red respectively. There remain only the Dutch and the Celtic. But the authorities we have quoted are all so emphatic that the cattle imported from the Low Countries were red and white, pied, not brindled, that the Dutch must also be absolved. There is but one weak spot in their defence, and that is a small one. The Low Countries, and some parts of France-say Normandy-were neither so far apart nor so definitely separated in an Englishman's mind, but that some of the cattle imported as from the Low Countries may have come from France. In this connection the "lyery" fleshed cattle referred to by George Culley must not be forgotten.

But, if the defence of the Dutch cannot be penetrated, then the blame lies with the Celtic cattle, and the Longhorns acquired their brindled colour from the blackish-brown cattle that were hiding, as it were, among the Celtic black ones. That being so, how long had this hiding continued? The answer to this question is the answer to the further question: which of these two races, the real black or the pseudo-black, arrived first in Britain? To that we can as yet give no answer. We can only suggest, since the pure black cattle in Britain were far more numerous than the brownish-black, since brownish- 
black cattle are also found in Jersey, Western France, and Switzerland, and remembering who were the early inhabitants of these places and of Northern France, that the brownish-black cattle may have been brought to Britain by the maritime inhabitants who had crossed over from the country of the Belgae for the sake of plunder and war before Cæsar's day. ${ }^{1}$

1 Cæsar's " Gallic War," bk. v. chapter xii. 


\section{VIII}

THE MELTING-POT

Having now identified the races of cattle that at one time or another have arrived in Britain and partaken $^{1}$ in the production of the breeds we now possess, we have next to inquire how each race modified or was modified by the races that arrived before or behind it. It has already been stated, that the great agricultural awakening commenced in the seventeenth century. From that time forward the desire for improvement grew keener and keener, and although, even at the present day, that desire is happily still strong, it might be said quite fairly, considering all the circumstances, that it reached its height about the junction of the eighteenth and nineteenth centuries. One of its many forms was to improve the livestock of the country. Men travelled long distances in order to procure cattle which they thought better than those of their own district, and as the cattle imported from the Low

1 A few black-and-white cattle and some other cattle-the Channel Islanders, for instance-have come in, but they have taken no part in producing our present breeds. 
Countries were larger and, in the opinion of eighteenth-century stock-breeders, better than those that were in Britain before them, it was to their descendants that men turned for stock with which to improve their own. The Longhorns, which were a combination of the Dutch and several of the races in Britain before them, were the great "improvers" till the end of the eighteenth century, when they were ousted from that position by the Shorthorns, and to some extent, the Herefords, two breeds also of composite character. But we shall better understand the process by which some of our modern breeds have been produced-the jumbling together, as it were, of different races and the emergence of new types of stock-after a short consideration of Mendel's theories, just as we should better understand how certain salts may be mixed together and new ones produced, by some knowledge of chemistry.

It is one of the greatest tragedies in science that Mendel's “Experiments with Plant Hybrids" ("Versuche über Pflanzen Hybriden "), which was published by the Natural History Society of Brünn in 1865 , remained unknown till the present century. It is impossible to imagine where we should have been to-day in our knowledge of heredity had Darwin only known of Mendel's work. But Darwin's own discovery so entranced the world that Mendel's was condemned to 


\section{EVOLUTION OF BRITISH CATTLE}

oblivion till years after both discoverers were dead. As it is, we must now go back, and partially, at least, revise some of Darwin's conclusions.

One of Darwin's main contentions was that races of animals vary, but, as he thought, slowly and constantly; that, to take a homely case, the neck of a giraffe is slightly longer than his father's, that his father's is slightly longer than his grandfather's, and so on backwards : thus, that the differences between a set of animals and their descendants a hundred generations younger are really the sum of all the small accretions added on (or taken off, for that matter) by each successive generation.

But De Vries has shown that sudden and observable changes take place among plants, and that these changes may be inherited: "Varieties have often been observed to appear at once, and quite unexpectedly in horticulture and agriculture." I Let us view De Vries's discovery as described by Professor Arthur Thomson 2 :-

"In 1886 De Vries began hunting about around Amsterdam for a plant which would show hints of being in what we may call a changeful mood. He tried over a hundred species, bringing them under cultivation, but almost all were disappointingly conservative. It seemed as if most

1 De Vries's "Species and Varieties," 1905, p. 16.

2 "Heredity," I908, p. 9 I. 
of the species around Amsterdam were in a nonmutable state. It is possible, as Weismann suggested in one of his first evolutionary essays (1872), that in the life of species, periods of constancy alternate with periods of changefulness. The human historian has often made a similar remark.

"In the course of his wanderings around Amsterdam, De Vries came across a deserted potato-field at Hilversum-a field of treasure for him. For there he found his long-looked-for mutable plant, an evening primrose (Enothera lamarkiana). Like its nearest relatives, Enothera biennis and Enothera muricata, which it excels in size and beauty of flowers, it probably came from America, where it is a native. It had probably 'escaped' at Hilversum about I875, and in the following ten years it had spread in hundreds over the field. It had been extremely prolific in its freedom; but that was not its chief interest.

"Its chief interest was its changefulness. It had, so to speak, frolicked in its freedom. Almost all its organisms were varying-as if swayed by a restless tide of life. It showed minute fluctuations from generation to generation; it showed extraordinary freaks like fasciation and pitcher-forming; it showed hesitancy as to how long it meant to live, for while the majority were biennial, many were annual, and 


\section{EVOLUTION OF BRITISH CATTLE}

a few were triennial; best of all, it showed what can hardly be otherwise described than as new species in the making.

"It is possible that the prolific 'multiplication in a new environment may have had something to do with the awakening of the impulsive mutability.

"In I 887, a year after his discovery of the potato-field, De Vries found two well-defined new forms-a short-styled $O$. brevistylis and a beautiful smooth-leaved $O$. lavifolia-distinguishable from the parent in many details. He hailed these as two new 'elementary species,' and he applied one of the crucial tests of specific or subspecific rank: Did they breed true? He found that it was so; from their self-fertilised seeds similar forms arose. Neither of the two new forms was represented in the herbaria at Leyden, Paris, or Kew; neither had been described in the literature of Onagracea. They seemed to be distinctly new. It is interesting to note that in 1887 there were few examples of these two new elementary species, and that each occurred on a single plot on the field. The impression conveyed was that each had arisen-by a sudden mutation-from the seed of an individual parent.

"The next chapter in the famous investigation began with a transference of samples of the new forms and the parent stock-partly as plants 
and partly as seeds-from the potato-field at Hilversum to the botanic garden at Amsterdam.

" The three stocks gave rise under cultivation to many thousands of individuals, which bred true along certain lines, and yet gave rise to other new forms. In short, De Vries had found a plant in the process of evolution.

"The predisposition to mutability-which remains a mystery-was present. De Vries gave it scope, and like the primeval gardener he had the pleasure of giving names to a crop of new creations which emerged before him. From each of these three samples there arose distinctive groups-which, if they had been found in nature, would have been reckoned as distinct species of evening primrose. But the most interesting feature was the apparent abruptness in the origin of the new forms. They seemed to rise by leaps and bounds, by organic jerks ; they illustrated what De Vries has called 'mutation.'"

It does not concern us here whether De Vries's mutations were the result of a new environment or of some other cause. The point for us is that while there may be variation in the Darwinian sense, there are also sudden changes when animals of different characters are bred together, and under certain circumstances these changes are inherited. Mendel's theory explains both the changes and their inheritance. Mendel's original experiments were made with 


\section{EVOLUTION OF BRITISH CATTLE}

plants, but, as similar results have been obtained again and again with animals, we may substitute animals for plants. When white cattle are mated with red, their progeny (first crosses) are roan; but when these roans are mated together, a quarter of their progeny return in colour to the white parent race and a quarter to the red parent race, while the remainder are roans again, like their parents. Mendel's theory explains such phenomena. He conceived the idea that an animal carries, from its very beginning, determinants which are going to decide, one its eventual colour, another its size, another its length of limb, and so on; and that a half of each determinant is inherited from each parent. Each determinant is therefore, as it were, bicellular, bouble-barrelled.

A roan animal's red parent carries a doublebarrelled determinant for redness, which we may

represent thus :

, while its white parent carries another for whiteness, which we may represent thus: $0^{0}$

When a red animal is mated with a white, their determinants meet, and the young, taking a half of that offered by each parent, starts off with a determinant, one half of which is for redness, the other half for whiteness, thus: 0 , and 
its coat is a mixture of red hairs and white-that is, roan. The proportions of the two kinds of hair vary greatly : the white hairs being sometimes so few that the roan is almost a red, and the red sometimes so few that it is almost a white. ${ }^{1}$

When roan crosses are bred together their progeny select their colour determinant one half from each parent, and the chances are one that both halves will be red; two that one will be white and one red; and one that both will be white. It may be a union of these

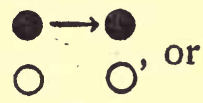
these
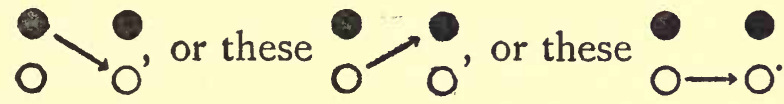

Consequently, from a sufficient number of matings, a quarter of the calves must be red, a half roan, and a quarter white.

Again, when red cattle are mated with roan ones, one half their calves are red, the other half roan. Combining the four little diagrams as above,

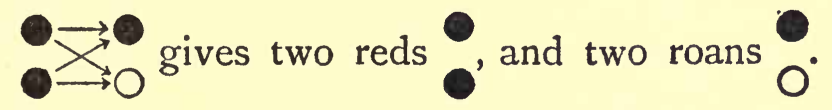

Further, when white cattle are mated with roans, one half their progeny are white, the other half roan. roans

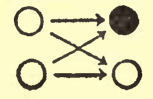
gives two whites

$\mathrm{O}$ and two

1 White cattle with the black or brown "points" of the "wild" park cattle behave as pure whites, and red and white flecked cattle behave as pure reds. 


\section{EVOLUTION OF BRITISH CATTLE}

The following table shows the average numbers of calves of each of these colours that may be produced by all the possible matings :-

\begin{tabular}{lcccrrr} 
Red $\times$ Red & $\ldots$ & $\ldots$ & $\ldots$ & $\begin{array}{r}\text { Red } \\
\%\end{array}$ & $\begin{array}{r}\text { Roan } \\
\%\end{array}$ & \multicolumn{1}{c}{$\begin{array}{r}\text { White } \\
\%\end{array}$} \\
White $\times$ White & $\ldots$ & $\ldots$ & $\ldots$ & 0 & $\circ$ & 100 \\
Red $\times$ White & $\ldots$ & $\ldots$ & $\ldots$ & 0 & I00 & 0 \\
Red $\times$ Roan & $\ldots$ & $\ldots$ & $\ldots$ & 50 & 50 & 0 \\
White $\times$ Roan & $\ldots$ & $\ldots$ & $\ldots$ & 0 & 50 & 50 \\
Roan $\times$ Roan & $\ldots$ & $\ldots$ & $\ldots$ & 25 & 50 & 25
\end{tabular}

Thus it will be seen that, although by crossing white cattle and red a new colour, roan, is produced, that new colour itself is unstable and throws back constantly to one or other parent race. A similar result follows when white cattle are crossed with black: the intermediate hybrid, as it is called in Mendelian phraseology, being in this case a blue roan.

But, although these intermediate hybrids are unstable, they may be the means of transferring the colour of one kind of cattle from that kind to another kind. The transference of the white colour of the Roman cattle to the black Welsh cattle is a simple case. A white Roman bull breeds with black Welsh cows and produces blueroan calves. These again breed together, and 25 per cent. of their calves are white. In other respects some of these white calves are Romans, some Welsh, and thus, in two generations only, some black Welsh cattle may be turned white.

Perhaps, for exposition's sake, a more striking 
case could be imagined. If one or more white Shorthorn bulls were put to a herd of red North Devon cows, their progeny would all be roans. At the same time, they would be intermediate between their parents in size, as well, perhaps, as in some other things which we may neglect for the present. If those roan crosses were bred together, 25 per cent. of their progeny would be white, 50 per cent. roan, and 25 per cent. red. At the same time, 25 per cent. of the whole would be Shorthorns in size, 25 per cent. Devons, and 50 per cent. intermediates. But, as the chances are absolutely against both colour and size varying together, there are reds, whites, and roans among the cattle of Shorthorn size, and reds, whites, and roans among those of Devon size. The whitecoloured cattle of Devon size are white Devons, from which any number of white Devons might be produced, and by the use of such cattle the whole red Devon breed could be made white in not so very many generations.

There are, however, hybrids which are not obvious intermediates, but which masquerade in the guise of one of their parents. The progeny of black and red cattle are black, yet they are hybrids nevertheless. When these masquerading hybrids are bred together, a quarter of their progeny are red, like one of their grandparents, and three quarters are black, like the other, but of the black ones only a third are genuinely black; 


\section{EVOLUTION OF BRITISH CATTLE}

the others are masqueraders-hybrids, like the roans, although they pretend to be otherwise.

The explanation is that, while one half of the colour determinant of these crosses is for blackness -derived from the black parent-and the other half for redness-derived from the red parentthe relationship between blackness and redness is such that blackness holds the mastery and obscures or hides redness. Redness is all the time latent, however. In Mendelian phraseology, blackness is dominant to redness, and redness is recessive to blackness.

These phenomena may be made clear diagrammatically. We shall use letters instead of circles, and, for convenience, we shall use capitals to denote the dominant characters and small letters to denote the recessive.

Black cattle mated with red produce masquerading black hybrids, thus-

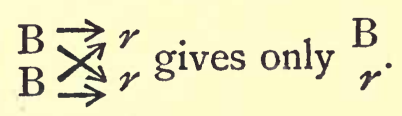

When masquerading black hybrids are bred together, their progeny receive their colour determinant, one half from each parent, and the chances are: one that both halves will be black, two that one half will be black and the other red, and one that both will be red. It may be a union of these, $\frac{\mathrm{B} \rightarrow \mathrm{B}}{r}$; or these, $\frac{\mathrm{B}}{r} \mathrm{~B}_{r}^{\mathrm{B}}$; or 
these, ${ }_{r}^{\mathrm{B}} \nearrow_{r}^{\mathrm{B}}$; or these, $\underset{r \rightarrow r^{\circ}}{\mathrm{B}} \mathrm{B}$ Consequently, from a sufficient number of matings a quarter of the calves are pure black, $\mathrm{B}$; a half are masquerading blacks, $\frac{\mathrm{B}}{\boldsymbol{\gamma}}$; and a quarter are pure red, $\stackrel{r}{r}$.

Again, when black masqueraders are bred back to pure black cattle, one half their progeny are pure black, the other half masqueraders. Thus $\underset{\mathrm{B}}{\mathrm{B}} \underset{\rightarrow}{\rightarrow}$ gives two pure blacks, $\mathrm{B}$; and two masqueraders, $\frac{B}{r}$.

Further, when black masqueraders are bred back to red, one half their progeny are masqueraders, the other half are red. masqueraders, $\underset{r}{\mathrm{~B}}$, and two reds, $\underset{r}{r}$.

These black masqueraders cause confusion, since they cannot be separated from the pure black ones by the naked eye; but, like the intermediate roans, they may also be the means of transmitting a colour from one set of cattle to another. For instance, red cattle of North Devon type were taken to the south of Ireland a century ago, or more, and crossed with the native black Kerry cattle. The result of the crossing and 


\section{IOO EVOLUTION OF BRITISH CATTLE}

recrossing was that some calves were pure black, others were masquerading blacks, and others were pure red. The red colour is not admired by Kerry breeders, and no attempt has been made to keep it; but, because of the difficulty of identifying and, so, eliminating them, when masquerading blacks are mated together, red calves are occasionally born. If these red calves were kept and bred from, the Kerry black breed could eventually be converted into a red breed. By doing this, the Highland breed of cattle has been changed from one that once was largely black to one that is now largely red.

But the Kerry breed is of further interest because, while the Devons transmitted to it their red colour in potentia, they also transmitted their shortness of leg. In this case shortness was dominant to length. The result of the crossing was that some calves were pure short-legged, others were masquerading as short-legged, and others were long-legged. Thus among each of the three different colours of Kerry cattlepure blacks, masquerading blacks, and redsthere are pure short-legged animals, masquerading short-legged animals, and long-legged animals. That is to say, among Kerry cattle now, as compared with Kerry cattle long ago, there are some possessing characters, redness and shortleggedness, which have been transmitted to them 


\section{THE MELTING-POT}

IOI

by another breed. Such short-legged cattle are distinguished from ordinary Kerries by being called "Dexters."

Still another case might be quoted. At one time the cattle of Suffolk were hornless and light dun, while their neighbours were horned and red. Breeders preferred the hornlessness of the one breed and the redness of the other. The hornless character is dominant to the horned; consequently, as a result of crossing horned and hornless cattle, there were produced pure hornless cattle, masquerading hornless cattle, and horned cattle; but, by continually selecting hornless ones to breed from, the masqueraders and the horned ones were worked out. When the light dun Suffolks were crossed by red cattle, there resulted yellow intermediate hybrids; but when these were crossed by red cattle, half their progeny were red. By the persistent selection of red-coloured cattle, the original light dun colour and its derivative yellow were eventually worked out. Thus the old Suffolks and their neighbours became one breed : the Suffolks giving up their colour and their neighbours their horns.

It is not necessary for us to consider cases in which three or more characters have been transferred from one breed to another. 
THE DUTCH SUPREMACY

WE have already shown that, in Mortimer's time, I716, there were Dutch cattle in Lincoln and Kent, and that by Culley's time, I794, they had completely conquered the east coast from Lincolnshire to the borders of Scotland. Unfortunately there were no Culleys to record their progress in the midlands and the counties on the west, but we can infer from the English "Agricultural Surveys," published about the junction of the eighteenth and nineteenth centuries, that the Dutch conquest was almost as complete in the west as in the east. The impression conveyed by these surveys is that from Lincolnshire westwards to Warwick and Worcester, and from there up the western side of the Pennine Chain as far as North Lancashire and Westmoreland, the older inhabitants had been swept out for many years. Indeed, some of the writers of the surveys thought the Dutch cattle around them were the old native race. These circumstances, along with the Herefordshire belief that Lord Scudamore 
imported Dutch cattle in the seventeenth century -it must have been before 1671, for he died then-indicate that Dutch cattle may have been brought to the west coast almost as early as to the east. It may be doubted, however, whether the eastern and the western conquests were exactly alike. On the east coast the Dutch invaders seized the land almost for themselves alone, while in the midlands and in the west it was rather an amalgamation of the invader and the invaded. The cattle on the east retained the characteristics they had brought with them from Holland, and acquired no others, while the cattle in the midlands and west eventually acquired characteristics drawn from both Dutch and British sources. The cattle of Hereford and some neighbouring districts acquired their red colour from their Anglo-Saxon ancestors, and their size and their white faces and underlines from Holland; while the midland and Lancashire cattle-the Longhorns-acquired their size and white back-stripe from Holland, and their various colours-red, yellow, mulberry, plum, dun, the brindles, and so on-from the red cattle in the south of their territory and the Celtic and other cattle in the north. It is also highly probable that the long and peculiarly shaped horns of the Longhorns are a direct or indirect-perhaps both - legacy from the cattle brought to Britain by the Romans. 


\section{IO4 EVOLUTION OF BRITISH CATTLE}

Thus these three kinds of cattle, the Herefords, the Longhorns, and the Shorthorns, the first two largely of Dutch descent, the last almost entirely so, were established in England in the first half of the eighteenth century. But the territories they occupied were too small for them. The Longhorns were the first to make this discovery, and, casting envious eyes on the fertile country to the south, they sent out wave after wave of their surplus population, until by the end of the eighteenth century they and their progeny by English cattle possessed it all as far south as the Sussex downs, leaving the comparatively less fertile outside rim to such as the Herefords, the Devons and Somersets, the Sussex, the Suffolks, and the Norfolks. ${ }^{1}$ To the east they were balked by the Pennine Range and the Shorthorns; to the north the prospect was less encouraging, but across the Irish Channel they found a promising outlet.

Ireland was ripe for the importation of superior bovines. The seventeenth century had been a century of " plantations "-Elizabeth's, James's, and Cromwell's. Much of the land had become the property of the English and Scots. The cattle of the country were of the same race as the small black Celtic cattle of Scotland and

1 The Dutch cattle that came to Kent and perhaps Essex made no great headway. The Kent cattle probably handed on their size to the Sussex. 
Wales, excepting, perhaps, in the south, where there may have been some small red cattle of North Devon type. Knowing the superiority of the cattle in England, many owners of land in Ireland sent there for cattle, and Lancashire and the western counties being most convenient for transit, as well, perhaps, as possessing the most superior cattle, were naturally resorted to. Eventually, as in the south of England, the Longhorn overran the most desirable parts of the country, and, at the time of Arthur Young's visit $(1776-78)$ they and their cousins that had been graded up from the original black Celtic stock, and were now for the most part pure Longhorns, were in possession of the great central plain of Ireland, from one side of the country to the other, and of the fertile valleys and smaller plains running into it from both sides: the native cattle having been driven into the higher and less fertile regions to the north and to the south. At the same time considerable numbers of Longhorn cattle were carried elsewhere for colonising purposes. They were carried into Wales, the north of England, Scotland, and even to the Orkney Islands, but in these at that time somewhat backward countries, although they left signs of their visits, they made no great progress.

Hemmed in on the south by the Longhorns, on the west by the Pennine Chain and the 
Longhorns, and on the north by the backward state of the country, the east country Dutch cattlethe Shorthorns-were prevented for a time from extending their territory. The state of the north in the beginning of the eighteenth century may be imagined from the fact that while there were many considerable provincial towns in the south, and two of them, Norwich and Bristol, had about 30,000 inhabitants, there were really only four important towns in the north, viz. York with I0,000 inhabitants, Edinburgh with 30,000 , Glasgow with 12,000, and Aberdeen with about I0,000. In those days a traveller might have travelled from London to York by coach, but beyond that he must have used pack-horses. The means of communication may have been good enough even for cattle of an improved breed, but the deplorable lack of winter food, especially in Scotland, was sufficient to prevent the Shorthorns spreading northwards quickly. Brigadier Mackintosh, a partaker in several rebellions and in many continental fights, while lying prisoner in Edinburgh Castle somewhere between 1719 and 1729 , thus describes how cattle were treated in Scotland: " Nor can it be otherwise in the supine ignorance our Farmers are in, in the Method of choosing the right ages of putting up to fatten their Beasts and the want

1 "An Essay on Ways and Means for Inclosing, Fallowing, Planting, etc., Scotland," 1729, p. I3I. 


\section{THE DUTCH SUPREMACY}

of every Provender fit to raise them: For they generally never stall any, but such Oxen as are no longer fit for the Yoke ; or Cows, but such as, the Goodwoman tells her Husband, are no longer good to breed or milk: These, for eight or ten weeks, they blow up with scalded Barley, Chaff, and Malt-grains ; that lean Rickle of Bones, is all the Butchers can pick up in Fife and Lothian, from Candlemas to June, even for our Metropolis. No other town is so well served. ... I am informed, that some Gentlemen of Edinburgh, send to Berwick for their Beef and Veal. . . . Methinks, it should raise the indignation, as well as Shame of all Scotsmen, as I cannot conceal it does very much mine, that our chief Town cannot, for 4 or 5 Months of the Year, furnish Meat for a Gentleman's Table, but we must send to England. . . . Let us inclose ${ }^{1}$ and furnish Stock of proper Maintenance for our Cattle for Winter and Spring, of Turneps, Fog and Hay, my Life, we shall raise our Beasts as high and fat proportionable to their Bone, as their Valley of Essam, let be their Berwick. . . . And I believe now, a great many English Gentlemen, who, in our Highlands, in the Month of May, see the Leanness the Country Beasts are then in, to the Degree they must be helped up when they fall or ly down of themselves, \&c., \&c."

But as the desire for agricultural improvement, 1 That is, fence common lands, etc. 
which had begun in the south and which had acquired such vigour after Tull and Townshend discovered how to grow turnips about I730, crept northwards, an outlet was made for the Shorthorns which they quickly made use of. Before the end of the eighteenth century they and their crosses were masters of the east of England and the eastern lowlands of Scotland from Lincolnshire to the Forth. And not only so, but some of them had already penetrated into Fifeshire to improve the cattle of that country, while from others which had found their way westwards across the mountains the modern Ayrshires were ere long to emerge. In the last quarter of the eighteenth century the great struggle for the possession of Ireland, in which the Longhorns were eventually to be driven from the field, was begun by the importation of Shorthorns from Holderness and Teeswater. Arthur Young (1776-78) reports having seen at least two lots of those first imported to Ireland at Armagh in the north and Doneraile in the south.

The West Country Dutch Shorthorn Cattlethe Herefords-had to wait many years till they found an outlet for their surplus population. They extended their original territory westwards ; towards the end of the eighteenth century they made a descent upon Ireland, in the midland counties of which they have retained their hold 


\section{THE DUTCH SUPREMACY IO9}

to the present day; but their great opportunity came in the nineteenth century when hardy grazing cattle were wanted for the ranches of North and South America and some British Colonies. 


\section{$\mathrm{X}$}

BAKEWELL

IT may be doubted whether the idea that their live stock might be improved ever took much hold of British farmers' minds before the arrival of the importations of cattle and other stock from Holland. At any rate it was not the overmastering idea it has since become. For one thing, they knew of nothing either very much better or very much worse than their own, unless, perhaps, on the common frontiers of two races, say the English and the Celtic, or here and there in the north, when the rievers returned from a raid far over the border. It is true that in "Seneschaucie," written not later than the time of Edward the First, it is laid down that the cowherd "must see that he has fine bulls and large and of a good breed pastured with the cows." 1 It is also true that several English sovereigns took steps to improve the breed of horses, and that Henry the Eighth imposed a fine of forty shillings on "lords, owners, and farmers of all parks and grounds enclosed as is above rehearsed,

1 Walter of Henley's "Husbandry," pub. I890, p. I13. 
who shall willingly suffer any of the said mares to be covered or kept with any Stoned Horse under the stature of fourteen handfuls." 1 And advice like the following is found in some seventeenth and eighteenth century writings: The cattle "in Somerset-shire and Glocester-shire, are generally of a blood red colour, in all shapes like unto those in Lincoln-shire, and fittest for their uses. Now to mix a race of these and the black ones together is not good, for their shapes, and colours are so contrary, that their issues are very uncomely: therefore I would wish all men to make their breeds, either simply from one and the same kind, or else to mix York-shire with Stafford-shire, with Lanca-shire or Darby-shire, with one of the black races, and so likewise Lincoln-shire with Somerset-shire or Somersetshire with Glocester-shire." ${ }^{2}$ Yet it does not appear that there ever was any clear idea of improving the cattle of the country till the seventeenth and the eighteenth centuries; and the first sign of it lay in the Dutch importations, or rather not so much in the importations themselves, for the original importers may have intended to keep the imported stock pure, as in the phenomenally rapid swamping of the native cattle by continued crossing with imported stock. "The means of

1 Ridgeway's "Origin and Influence of the Thoroughbred Horse," 1905, p. 360.

2 Markham's "Cheap and Good Husbandry," 1683, p. 70. 


\section{2 EVOLUTION OF BRITISH CATTLE}

improvement, in the established practice of the kingdom at large, are those of selecting females from the native stock of the country, and crossing them with males of an alien breed." 1 It was by such crossings that a few breeders in the English midlands came to possess some cattle that were better than their neighbours'.

Then came Robert Bakewell, the master of them all, to show how those somewhat casually obtained improvements might be conserved and perpetuated. Results similar to those obtained by the midland farmers may have been obtained much earlier elsewhere-in Hereford by Lord Scudamore, for instance, or in Lincolnshire-but there is no evidence of Bakewell having had any forerunner.

The first part of the story may be told by Youatt." "It was not, however, until about the year 1720 that any agriculturist seemed to possess sufficient science and spirit to attempt the work of improvement in good earnest. A blacksmith and farrier, of Linton, in Derbyshire, on the very borders of Leicestershire, who at the same time rented a little farm, has the honour of standing first on the list. His name was Welby. He had a valuable breed of cows which came from Drakelow House, a seat of Sir Thomas Gresley, on the

1 Quoted from Marshall's "Rural Economy of the Midland Counties," published, 1790, in "The Complete Farmer," 4th ed.

2 "Cattle," p. 190. 
banks of the Trent, about a mile from Burton. $\mathrm{He}$ prided himself much in them, and they deserved the care which he took in improving them and keeping the breed pure ; but a disease, which defied all remedial measures then known, broke out and carried off the greater part of them, thus half ruining Welby, and putting a final stop to his speculations.

"Soon after this Mr. Webster, of Canley, near Coventry, distinguished himself as a breeder. He too worked upon Sir Thomas Gresley's stock, some of whose cows he brought with him when he first settled at Canley. He was at considerable trouble in procuring bulls from Lancashire and Westmoreland, and he is said to have had the best stock of cattle then known. One of his admirers says that 'he possessed the best stock, especially of beace, that ever were, or ever will be bred in the kingdom.' . . . Little more is known of Mr. Webster than that he established the Canley breed, some portion of whose blood flowed in every improved long-horn beast.

"The bull, Bloxedge, the Hubback of the longhorns, and, like him, indebted to an accident for the discovery of his value, was out of a threeyear-old heifer of Mr. Webster's, by a Lancashire bull, belonging to a neighbour."

Now came Bakewell. He was born, "early in the year 1726, at the Grange, Dishley, two miles north of Loughborough, in the county of 


\section{4 EVOLUTION OF BRITISH CATTLE}

Leicester." ${ }^{2}$ He was come of a family distinguished for centuries in both Church and State. "The most remote ancestor named in the records of the family was Leverrettus, Thane of the King, and King's Chancellor in the reign of Henry II., presented to the rectory of Bakewell, in the county of Derby, in the year I I58." The Grange farm was 440 acres in extent, and Bakewell's father, who had always the reputation of being one "of the most ingenious and able farmers of his neighbourhood," died in I773, when he was 88 years old, and when Bakewell was 47. It is thus possible that some part of Bakewell's work may have been traceable in knowledge, thought, or action to his father. At least, in their improvements, other than those connected with stock-breeding, there was a clear continuity.

Prothero, in his "Pioneers and Progress," tells us that Robert Bakewell "resembled the typical yeoman who figures on Staffordshire pottery, 'a tall, broad-shouldered, stout man, of brown-red complexion, clad in a loose brown coat and scarlet waistcoat, leather breeches, and top boots.' In his kitchen he entertained Russian princes, French and German royal dukes, British peers, and sightseers of every

1 The information about Bakewell is drawn mostly from a paper by W. Housman in The Fournal of the Royal Agricultural Society of England for 1896 . 
degree. He never altered the routine of his daily life. 'Breakfast at eight; dinner at one; supper at nine; bed at eleven o'clock; at halfpast ten, let who would be there, he knocked out his last pipe.'" Clearly another Miller o' Dee: "I care for nobody, no, not I, and nobody cares for me": the kind of man who, having discovered his way, would stick to it!

For his time and occupation, Bakewell was a great traveller. In early life he "often left his home to travel about England." "He saw much of the west of England"; he saw the north-west and the south-west; he saw Yorkshire, Lincolnshire, and Norfolk; and he also travelled in Holland. Whether he travelled to find or travelled and found cannot now be told-probably he did both-but at one time and another he brought home the choicest of their stock from several of the places he visited: cattle from the borders of Westmoreland, Lancashire, and Yorkshire, sheep from Yorkshire and Lincolnshire, and horses from Holland. Here we are concerned only with cattle.

One statement regarding Bakewell, namely, that he thought the Devon cattle incapable of improvement by crossing with any other breed, indicates that, at one time, Bakewell held his neighbours' views as to how cattle should be improved, and this is confirmed by the fact that his stock were gathered from herds in different 


\section{6 EVOLUTION OF BRITISH CATTLE}

parts of the country, and that the cows he bought from Mr. Webster of Canley were put to a bull from Westmoreland. From the time, however, when he obtained that Westmoreland bull, which was somewhere about i760, Bakewell continued to put his own stock to his own, regardless of their relationship and of the custom and sentiment of the country. It must also be remembered that he had probably tried this system with sheep before adopting it with cattle.

Several reasons might be imagined for Bakewell having adopted the system of in-breeding. He was a great traveller, a close observer, and an unparalleled judge. $\mathrm{He}$ must have seen how animals came truer to their kind when bred pure, and how irregular were the progeny of cross-breds; and he may have argued that the mating of close relations was the very essence of pure breeding. Or he may have been a pre-Darwinian Darwinist, and argued that an accumulation of good qualities could only be secured by their continued infusion. Or, still more likely, failing to find a better bull than Twopenny-the produce of the Westmoreland bull and a Canley cow-and fearing to use a worse one, he may have been compelled, sentiment or no sentiment, to stick to his own. This view is supported by Marshall, who was deeper in Bakewell's confidence than any other writer, and who was, to some extent, the 
expositor of his ideas : "The argument held out in its (in-breeding's) favour is, that there can be only one best breed; and if this be crossed, it must necessarily be with an inferior breed; the necessary consequence of which must be an adulteration, not an improvement."

In any case, Bakewell adopted the system of in-breeding, and, looking back, we can now see how it was possible for him to have done what he did. He came upon the scene during the great agricultural transition and near the beginning of the rise in British industry and commerce. Formerly the cow had been valued for her milk, the bullock for its labour, the sheep for its wool, and the horse for its strength and weight in battle. Now the horse is to split into two kinds, one valued for its strength, the other for its speed, and the former is to drive the bullock from the plough to the feeding stall. At the same time, the new agricultural discoveries and the new crops are to allow the bullock to be fattened off at an age at which, in former days, he would have been beginning his career in the plough and the waggon. Now it is not a bullock that will grow for three or four years and remain active and lean for a similar period that is wanted, but one that will fatten quickly and easily at the end of his period of growth. Bakewell saw that a new kind of

1 "The Complete Farmer," 4th ed., under article "Cattle." 


\section{8 EVOLUTION OF BRITISH CATTLE}

animal must be bred from. Before his time calves that showed a tendency to fatness were turned into veal, while those not showing this tendency were retained. Bakewell reversed the process, and secured animals likely to breed him stock for the butcher rather than for the plough.

After long observation, with close inspection not only of the living but also of the animal postmortem, and with many experiments in the use of such feeding stuffs as were then in use at Dishley, Bakewell set up a type for himself and to that type bred persistently. With the light cast upon Bakewell's work by Mendel's discovery we can now see that some of the stock from which Bakewell bred may have been mere masqueraders and must have produced him not only masqueraders again but also some others that were frankly undesirables. Bakewell's original stock were certainly not pure, for they were drawn from the north and from the south, from parts of the country in which the recently imported Dutch cattle, themselves possibly of several breeds, had mingled with several others. To eliminate from these those that did not breed true to the type he desired, Bakewell took the quickest and surest method, namely that of mating close relations; for in those days of almost haphazard breeding, two closely related animals were much more likely to be pure for the 
same characters, than two animals drawn from different parts of the country or even of a county.

Apart from the fact that he was a man of outstanding ability, power, and perseverance, there are several points in connection with Bakewell and his work that will bear reiteration :

(a) He was an unparalleled judge of stock.

(b) He was at enormous pains to secure the best stock in the country for his purpose.

(c) Having secured these, he bred from remarkably close relations.

(d) He ruthlessly eliminated undesirable stock.

The truth of this last statement may be inferred from the facts that he educated breeders' tastes to a change of type, that from such mixed foundation stock as he began with he must have bred many undesirables, and that he used his bulls till they were very old and that upon their near relations.

The accompanying diagram, showing the pedigree of two of 
Bakewell's bulls, Twopenny and D, and of D's son Shakespeare, bred by Mr. Fowler of Rollright in Oxfordshire, will indicate Bakewell's system.

The figures in brackets attached to a bull's name indicate, approximately, the date of its birth.

In addition to being the great pioneer in the art of stock-breeding, Bakewell also took the lead in organising a system whereby the "blood" of his stock was disseminated among the stock of other breeders, while at the same time its connection with the fountain-head was not necessarily broken. A good many of his bulls and some of his cows were sold outright. Even in Ireland Arthur Young (1776-78) reported twelve or fifteen cases in which cattle had been brought direct from Bakewell. But to farmers in his own neighbourhood Bakewell arranged to let out some of his bulls for a season, at the end of which they returned again to Dishley. For instance, Bakewell's bull D was once let to Fowler of Rollright.

This system was advantageous to men of smaller means, as well as to Bakewell, for, if he discovered that any animal which had been let out produced unusually good stock, he could recall that animal for his own use at the end of its season. This system was adopted by other Longhorn breeders and in breeds that were established subsequently to the Longhorns.

It has often been argued that the system of 
breeding which Bakewell established must be a wrong one, since the breed which he did so much to improve, and which at one time overran a great part of England and almost the whole of Ireland was well-nigh extinct within a century of the time when Bakewell was in his zenith. But it must be remembered that another type of animal has been in demand since Bakewell's day. The Longhorns were graziers' cattle-slow to mature as we now understand them, and capable of withstanding the severity of winter in the open air. The great increase of tillage farming in the east of England and of dairy farming in the neighbourhood of large cities demanded a bullock that would turn turnips and straw quickly into beef in a stall or covered shed and a cow that also in the house would produce a large quantity of milk and afterwards fatten quickly. If only for its horns alone, the Longhorn was not the animal to meet this demand.

But the greatest argument for the Bakewellian system is that the breeds that superseded the Longhorn were originated, and have been maintained, in the same manner. Besides, to say nothing of his horses, the blood of Bakewell's Leicester sheep, which were equally or more in-bred than his cattle, now flows in the veins of every "longwooled" sheep that trots, and is still alive in almost absolute purity in two breeds - the Leicesters and the Border Leicesters. 


\section{$\mathrm{XI}$}

BLENDING AND SORTING

The East-country Dutch cattle-the Shorthorns - pursued a course somewhat similar to that of the Longhorns. In the territory they had won, however, they mingled much less with the natives, but rather drove them out before them. As we have already seen, they pressed northwards, and a branch, bending westwards, shared in producing the modern Ayrshire. No doubt, native blood was absorbed here and there, only for its outward tokens to be eliminated again in a few generations.

But in Yorkshire there was a permanent amalgamation from which the modern Shorthorn is descended. Storer ${ }^{1}$ mentions a number of herds of domestic white cattle in the north of England, some of which, if not all, were in existence before the Dutch invasion. In the first half of the eighteenth century stock were distributed from at least one of these herds, Studley Royal, near Ripon, which had at that time a high reputation over West Yorkshire

1 "Wild White Cattle of Great Britain." 
and Durham. By uniting with these cattle the Dutch Shorthorns absorbed the white colour of the Roman cattle and along with it the roan, which is a hybrid between the Dutch and Roman colours. About the same time the Shorthorns also absorbed the blood of some of the native black cattle, but the black colour at any rate was soon bred out, while, even .... to the present day, the blood of Anglo-Saxon red cattle has been frequently absorbed, the colour in this case to be retained.

Having been originally of several types, as Culley told us, and having absorbed this strange blood in England, the Shorthorns also required a Bakewell; and him they found in Charles Colling, who had been a pupil with the great master himself. The following diagrammatic pedigree of Charles Colling's great bull Comet will show how closely he followed Bakewell.

Here, again, we have a breeder who, like Bakewell, started with the best stock he could find, and, by inbreeding, eliminated the chances of uncertainty in their progeny; and 


\section{I24 EVOLUTION OF BRITISH CATTLE}

his system, much modified, has been adopted by the leading Shorthorn breeders down to the present day. How much this means to a breed can be inferred from the fact that the blood of the stock of the highest class breeders soon permeates a breed through the demand made upon it for breeding purposes by other breeders. Thus, at the present day there are no Shorthorns which are not descended from Charles Colling's Comet again and again.

Among the Shorthorns, as among the Longhorns, there was first a mingling of races and afterwards a retention of the desirable and an expulsion of the undesirable characters produced by the mixing. All other breeds have gone through the same process of mixing first and purification after, some to a less, others to a greater extent. For instance, the white colour has been expelled from pure-bred Welsh cattle, the hornless character and the light dun colour have been expelled from Somerset and Devon cattle, and while the Norfolks and the Suffolks have amalgamated, the former have given up their horns and the latter their colour; but, if we take a short survey of the history of Aberdeen-Angus cattle we shall see the process from more sides than in any other breed, and at the same time get a glimpse perhaps of what may be possible in the future.

At the present day Aberdeen-Angus cattle 
are hornless, similar in weight to Shorthorns and Herefords, and black, with occasional white markings upon the back underline. In the stock-breeder's sense of the term the AberdeenAngus breed is pure; but the irregular occurrence of white on the underline suggests that from a more stringent point of view the purity is not absolute. For that matter, it is inconceivable that any set of animals of more than one cell -or even of one cell, perhaps-can ever be absolutely pure.

But other irregularities sometimes occur, although with less and less frequency as time goes on. A red calf, a calf with a white spot on its face, another with one or more white flecks on the body, another with "scurs," that is, small epidermal growths attached to the skin and not to the skull, are not entirely unknown. Twenty or thirty years ago such phenomena were more common than now. At that time a calf with a brown stripe down the back and a tan muzzle, another with brindle markings, and another with short horns was not a ferlie-was not a marvel. Sixty or seventy years ago these phenomena were all common, and horned and hornless cattle, many of the former the ancestors of the present-day hornless cattle, competed together for prizes even at the shows of the Highland and Agricultural Society of Scotland. A century ago the horned and 


\section{I26 EVOLUTION OF BRITISH CATTLE}

the hornless grew up side by side not only on neighbouring farms but in the same fields, claiming frequently to be children of the same parents. At the same time, there were colours and markings among them not now seen at all: dun, yellow, "what Youatt called 'silvercoloured yellow," and white stripes along the back and belly. Many, too, of both kinds were not much more than half the weight of their present-day descendants.

Still further back-say a hundred and fifty years ago-they were all, or nearly all, of this smaller size; but the horned kind were in the majority in the inland parts, while the hornless kind, which were creeping inwards, prevailed near the coasts. Beyond that we have no direct evidence, but tradition says the inland cattle were originally horned and the maritime cattle hornless. So, do we not eventually reach back to the arrival of the long-headed, high-polled, hornless whity-grey or light dun Scandinavian cattle upon the coasts of Scotland, and are we not reminded of the traditional battles between Danes and natives and between the white Danes and the black Danes in the neighbourhoods of Cruden in Aberdeenshire and Lunan Bay in Forfarshire?

The first crosses between the Scandinavian cattle and the black horned natives were dun hornless masqueraders, which, when they were 
bred together, produced blacks (25 per cent.), duns (50 per cent.), and light duns (25 per cent.), among each kind of which there were horned cattle (25 per cent.), hornless masqueraders ( 50 per cent.), and hornless cattle ( 25 per cent.). That is to say, among sixteen cattleany number might be taken-the chances were that there were 4 blacks (I horned, 2 hornless masqueraders, and I hornless), 8 duns (2 horned, 4 hornless masqueraders, and 2 hornless), and 4 light duns (I horned, 2 hornless masqueraders, and I hornless).

Again, when the first crosses-the dun hornless masqueraders-were bred with the natives, there were produced, blacks ( 50 per cent.) and duns (50 per cent.), among each kind of which there were horned ( 50 per cent.) and masquerading cattle (50 per cent.). Thus, if farmers had a predilection for either of the two new productionsthe black hornless or the light dun hornedthey had merely to keep on breeding from these, and, in time, they would have nothing else. There being no deception about the colours, it is easy to see how the whity-grey or light dun vanished long ago, and the dun lingered on a while longer, while the hornless masqueraders, a gradually decreasing number, kept the horns bobbing up till comparatively recent times.

The blackish-brown cattle, the "foundlings" as we have called them, the date of whose 


\section{I28 EVOLUTION OF BRITISH CATTLE}

arrival upon the scene we have been unable to fix, produced brindles with both races-dark brindles with the black natives and light brindles with the Scandinavians. Here again, there being no deception, or, at any rate, only a slight one, for dark brindle is sometimes very nearly black, we can understand how, when black became the favoured colour, the brindles and their blackish-brown parent would gradually disappear.

But other races intervened-the Anglo-Saxon red race-whether openly and frankly in earlier days, or, disguised in their partial progeny the Longhorn, early in the eighteenth century; the Longhorns themselves, with their white finchbacks and white underline; and lastly, the Dutch flecked race, first in the guise of Fifeshire cattle, ${ }^{1}$ and, later on, as Shorthorns. And these races left their marks, some to be eliminated easily, others with difficulty. When red cattle were bred with blackish-browns and light duns, they produced brindles and yellows, and these, being unwelcome, were bred out quickly; but, when bred with black cattle, they produced black masqueraders. We can thus understand why an occasional red calf turns up. Masqueraders are difficult to deal with, and, when two of them meet, there is one chance in

1 There is a probability that these cattle may have absorbed Dutch blood direct from Holland before the Shorthorn invasion. 
four of their progeny being red, as may be seen from this Mendelian scheme-

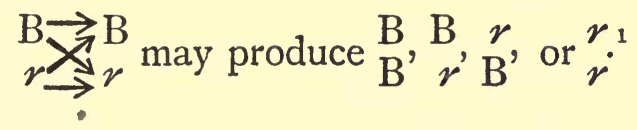

The white markings of the Longhorn are dominant to black on the same parts of the animal, and, being always visible, were easily eliminated. So far as our present knowledge goes, the white flecks seem to have been recessive characters, which again would account for the difficulty of breeding them out.

But perhaps the most important character which the Aberdeen-Angus cattle received from other races is their size. Crossed again and again by larger breeds, they eventually became as large as the cattle by which they were crossed. Whether the first crosses were intermediate or masquerading hybrids is not absolutely clear, but in any case, the initial crossing and the continued selection of the larger animals for breeding purposes resulted in a small breed being converted into a large one. The following quotation, ${ }^{2}$ part of which is irrelevant as regards size

1 When red cattle were bred with duns, the hybrids of light dun and black, they produced blacks and yellows, thus-

$$
\underset{\mathrm{R}}{\mathrm{R}} \underset{\mathrm{T}}{\rightarrow} \text { ives }{ }_{\mathrm{B}}^{\mathrm{R}} \text { (black), and }{ }_{\mathrm{L}}^{\mathrm{R}} \text { (yellow). }
$$

${ }^{2}$ A part of this communication was quoted in the chapter on the Norse Cattle. 


\section{I30 EVOLUTION OF BRITISH CATTLE}

but is of supreme interest otherwise, indicates that the crosses between the small breed and the large were intermediate hybrids. It is a communication to the authors of the "History of Polled Aberdeen or Angus Cattle," from Mr. William Forbes, an Aberdeenshire farmer, whose grandfather was a farmer in Buchan (East Aberdeenshire), and bred polled cattle :-

"The cattle in Buchan about half a century ago and earlier might be said to have consisted of horned and polled black cattle in about equal proportions. The polled cattle were of two classes, one large and another small. I knew the small kind well. They were rather puny creatures, always thin in flesh, and very badly used. They were pre-eminently the crofter's cow, as they were able to live through the winter on the straw of oats and bere, and water, if necessary. Of the larger portion of the cattle, about one-half were jet black, and often the whole underline was white. They could not stand starvation so well as the small polls, but with better treatment they gave a heavier yield of milk. A few were of a dull-red colour, but they were not so high in favour as the brindled cattle. The polled cattle were the dairy stock. The butter they produced was very fine in summer and autumn, but hard and white in winter. The establishing of a beef trade with

1 Macdonald and Sinclair, published I883, p. 72. 
England, and the introduction of Shorthorn bulls and turnip husbandry, opened up a new era for Buchan. The native cattle fattened well, and money was made by doing so. Shorthorn bulls were introduced and put to all kinds of cows. Often when a Shorthorn bull was mated with a small polled cow, the produce was a black poll of the finest character-immensely superior to either of the parents. When a heifer of this stamp was again put to a Shorthorn bull, the result was quite as fine a black poll, of still larger size. If the produce were also a heifer, and mated with a pure Shorthorn bull, the result was still a poll, yet larger in size, but bluishgrey in colour. If a heifer again, and put to a Shorthorn bull, the produce was once more a grey poll, probably lighter in colour. When this form of crossing was continued further, Shorthorn colours appeared, sometimes with scurs, but oftener with the regular short horns of the male parent. I observed this experiment tried in several cases, with exactly the same result. With the larger polls with white underlines, the horns and colour of the Shorthorn bull were earlier transmitted to the produce, generally at the second or third crosses. I therefore look upon the small polls without white spots as the pure original Buchan Humlie."

Thus, with the characters they now possess drawn from several sources, the Aberdeen-Angus 


\section{I32 EVOLUTION OF BRITISH CATTLE}

cattle have come down to the present day-not, however, without their Bakewell to establish them, and his successors to maintain them in equilibrium.

The Aberdeen-Angus Bakewell was Hugh Watson, the son of farmers and polled cattle breeders on the borders of Forfar and Perth, who, in 1808 , at nineteen years of age, got a farm for himself and six of his father's "best and blackest cows, along with a bull, as a nucleus for an Angus doddie herd." Within a month or two he went twenty miles north to Brechin, the great market of those days, and bought "the ten best heifers and the best bull he could procure." And more than half a century later, when his work was done, Hugh Watson's cattle were almost, if not entirely, descended from the cattle he began with in 1808 .

How far Watson was driven to the system of in-breeding by force of circumstances, and how far by example, cannot be told; but it must be remembered that, being another unparalleled judge, and having begun his herd with the best he could find, it was afterwards difficult for him to get other cattle as good as his own. It must also be remembered that Charles Colling's Comet was sold for a thousand guineas in the year I8Io.

By exhibiting the last three or four generations that led up to Hugh Watson's greatest bull, 
Old Jock, born in 1842 , we shall see the Bakewellian method as carried out in its most intense form. Then, by another diagram, we shall see the streams through which the blood of Old Jock flowed down to some of his most illustrious descendants, first at Mains of Kelly and Kinnaird, in Forfarshire, then at Tillyfour, in Aberdeenshire, and finally at 垔 Ballindalloch, in Banffshire, the places to which in succession Aberdeen-Angus breeders have turned for stock bulls and higher class cows and heifers. A short examination of these diagram pedigrees will show that the inbreeding begun by Hugh Watson was continued, though with less intensity, by his successors. The extraordinary concentration of Old Jock blood in Aberdeen-Angus cattle to-day may be gathered from the fact that it would be difficult, if not impossible, to find

1 In the "Aberdeen-Angus Herd Book," and in other writings there is some confusion as to Old Jock's pedigree; but, after considerable inquiry and examination, the above seems to be its last few generations. 
I34 EVOLUTION OF BRITISH CATTLE

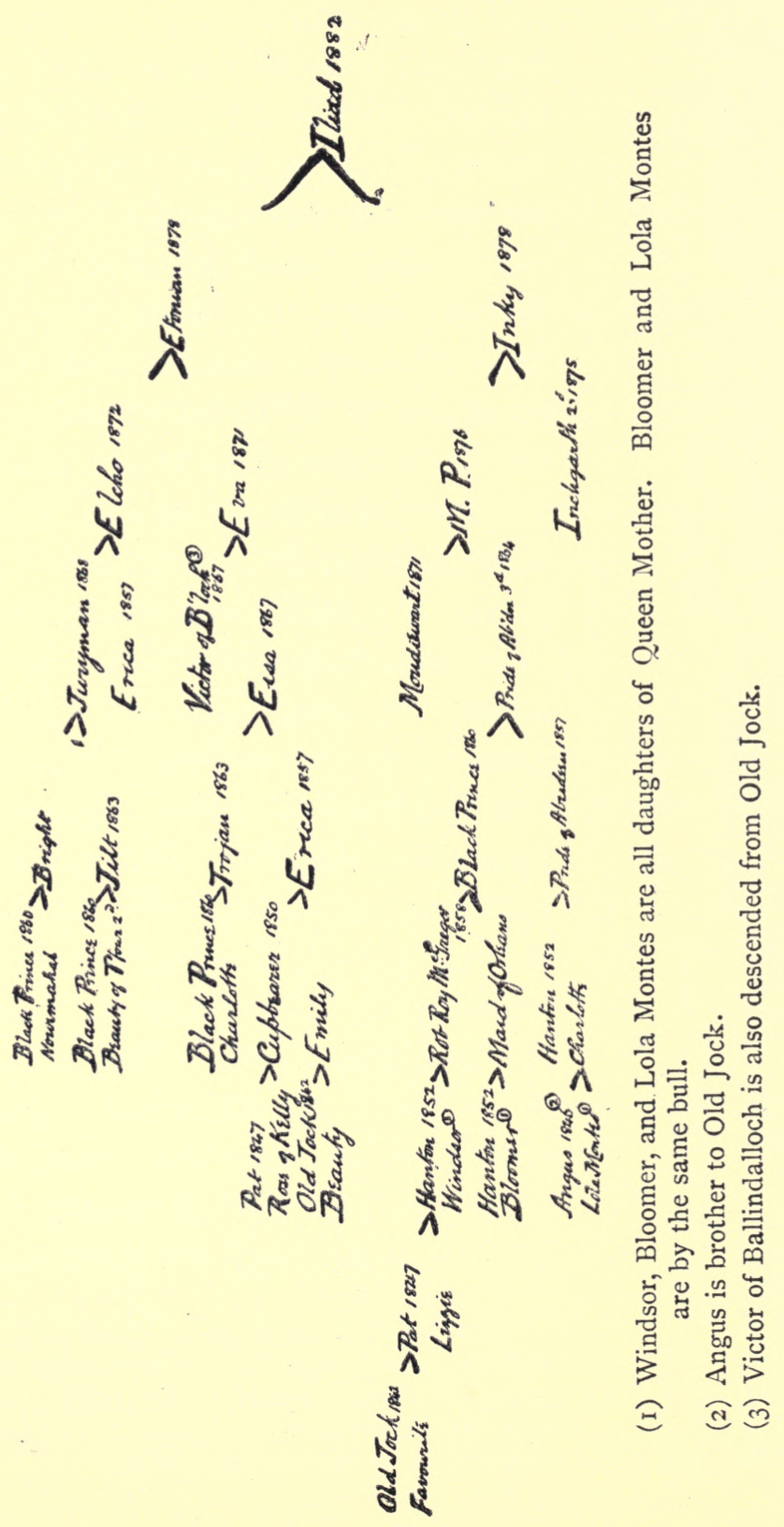


an Aberdeen-Angus animal born within the last four or five years which is not descended from Iliad more than once.

One other Scots breed-the Highlanders-is also of some interest. Its basis was the original black Celtic cattle. The browns or (in Gaelic) donns came in at some time or other, and brindles appeared from the cross. The hornless light dun Scandinavians came in and produced hornless cattle and duns with the black ones, and further brindles with the donns. Subsequently red English-some of them with Longhorn markings -reached the Highlands, and there resulted another brindle with the donns, and a yellow by crossing with the light duns; but the Longhorn markings and the hornlessness got from the Scandinavians have been eliminated. The following diagram will show how the present Highland colours were produced from the original four :-

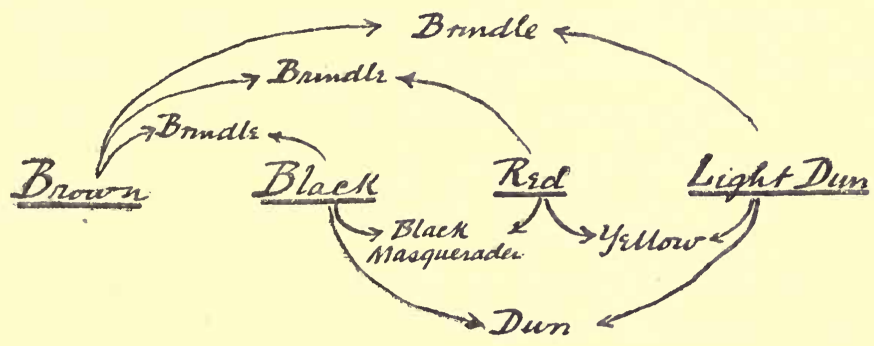




\section{XII}

SPECULATIONS

IT is not the purpose of this book to deal fully with the principles of stock-breeding, but some phases of the question raised by the preceding chapters might be referred to with interest at least. It cannot have escaped the notice of any one who has read the last few chapters how large have been the parts played by crossing and inbreeding in bringing our British breeds of cattle to their present position. At the same time, it must be admitted that it is not clear that everything accomplished has been due to the action of those two factors. There may still be something more-there may still be the constantly accumulating change which Darwin believed in, although it is hard to think that changes which formerly took thousands and thousands of years may now be induced by man's action in two or three centuries; and there may also be De Vries's mutations or organic "jerks," the results of changed conditions in food, climate, or any other form of environment. So far these questions must be left undecided; but it seems impossible 
to account for the extraordinary milking powers of some animals and the beef-producing powers of others without the assistance of Darwin or De Vries or somebody else. Did any Dutch cows produce twelve hundred gallons of milk a year, or did any Dutch bullocks weigh thirteen or fourteen hundredweights at less than two years old two hundred years ago; or if they did not, could they have done so provided they had received similar treatment to that received by their descendants in Britain to-day? To answer these questions is of course to answer the former ones; but as we have no data before us to answer these, the former must also remain undecided.

These remarks lead to another phase of the same question, namely, Is it possible, without crossing, to endow a set of animals with characters which none of them already possess? For example, is it possible, without crossing, to make the North Devon as large as the Shorthorn, or as black as the Aberdeen-Angus? If Darwin's theory be correct, then it might be possible, but how long would it take? If De Vries's organic jerks occur, it may also be possible, but who is to have the patience to sit down and watch for them? On the other hand, it must be remembered that the origin of all our improved breeds has been in the selections of such men as Bakewell and his kind, of unparalleled judges as we 


\section{${ }^{1} 3^{8}$ EVOLUTION OF BRITISH CATTLE}

have called them; and that when the originally selected type had been steadied or fixed by inbreeding, the breed as a whole was gradually graded up to their standard by persistent mating with the selected type.

Within the above question lies another much smaller to a breed but larger to many an individual breeder: Is it possible for a second class herd to be raised to the first class without recourse to the assistance of first class stock? Again the answer must be the same: that it may be done; but in how many years, or in how many lifetimes? Few, if any, of our first class herds have been raised in this way. Some may have been raised by continued infusion of the highest into lower types-by grading, as it is called-but most of our great stock-breeders date their entry into the highest ranks from the time they acquired the highest class of stock and commenced to eliminate the lower.

Among stock-breeders generally there is a very strong aversion to in-breeding, although it was the method of the great pioneers and is still the method in a modified form, called line breeding, among breeders of the highest class. The origin of this aversion would be difficult to trace, although it has been frequently suggested to have been biblical. It existed in Bakewell's day and how long before we do not know; but if it existed in much earlier days it is difficult 
to see how farmers were able to make their practice agree with their theories. Nature herself seems to have no special aversion to the practice. The wild bull keeps possession of his own glen and his own herd till he is ousted perhaps by some stranger from across the hills, but more likely by his biggest brother or his eldest son who so far has been kept at a distance by the fear of his parent's horns. According to some authors the evils of in-breeding are almost innumerable: barrenness, lack of size, milk, constitution, hair, and so on ; tuberculosis, rheumatism, leanness, fatness, long legs, short legs, brainlessness, and every other form of retrogression. Families and tribes that once had the highest reputation are now no more, nearly extinct, or relegated to an inferior position. But would the type that was best half a century ago be the best to-day? Have not some that formerly were less regarded now found favour? Besides when a tribe or type gets into a prominent position, and its individual members rise in money value and so get into the hands of wealthier men but poorer judges, who is to see to their proper mating, and the elimination of such animals as are below the standard? And when animals whose money value is large get into the possession through inheritance or otherwise, of poorer men but better judges, how are these men to determine whether their purse or their taste is 


\section{I40 EVOLUTION OF BRITISH CATTLE}

to prevail ? In the face of some of the preceding chapters and these considerations, in-breeding must escape the charges against it with at least the Scots verdict, not proven. When once a breed has been established, however, that is to say, when it has reached such a degree of steadiness that it can be called "pure," the need for in-breeding is greatly decreased.

But what of the future? Does the past offer any guide? Previous to the discovery of Mendel's work, the dictum of the past as to the conditions for success in cattle-breeding would have been-

(i) A good judge.

(ii) Good stock.

(iii) Line breeding with old-established and in-breeding with new breeds.

(iv) Ruthless elimination of the unfit.

But although Mendelism would not alter the dictum it would increase the breeder's power by increasing his knowledge of the working of Nature's laws. Already in this paper such of the Mendelian knowledge as is yet known with regard to cattle is referred to. So far that knowledge is not great, and it is largely concerned with comparatively unimportant matters, like colour, for instance; but as the signs by which Mendelian characters can be identified become better known, it is hoped that information about much more important matters than colour may 
be gathered. And, when this happens, things that now come and go in the most mysterious manner will be under the cattle-breeder's control.

Perhaps the best way to make the possible power of Mendelism clearer is to consider what signs ought to be looked for in reference to a matter of some considerable importance, namely, milking capacity. This capacity varies enormously, a fact which in itself suggests a Mendelian phenomenon. Some bulls have a reputation for leaving good milking, others for leaving poor milking, stock : another circumstance pointing to the same conclusion. If milking capacity be a Mendelian phenomenon, then the way in which it will show itself will depend upon whether the hybrids between high and low milkers are intermediates or masqueraders. It must be remembered that other factors interfere with milking capacity as such alone. The cow's size, age, and health might be mentioned, for instance. If these other factors can be eliminated, then, if the hybrids are intermediates, there will be three grades of cows, viz. high grade, medium, and low grade. The cows' grade being manifest by their yield of milk, the difficult part of the problem is to determine the grade of the bull; and for this there is only one test, the test of breeding. He is either high grade, middle, or low grade. The following, 


\section{I42 EVOLUTION OF BRITISH CATTLE}

table will show the grades of stock each grade of bull should get with each grade of cow :

High grade bull with high grade cows should get

$\begin{array}{ccc}\begin{array}{c}\text { High } \\ \text { grade } \\ \text { stock. }\end{array} & \begin{array}{c}\text { Middle } \\ \text { grade } \\ \text { stock. }\end{array} & \begin{array}{c}\text { Low } \\ \text { grade } \\ \text { stock. }\end{array} \\ \begin{array}{c}\% \\ 100\end{array} & - & - \\ 50 & 50 & - \\ - & 100 & - \\ 50 & 50 & - \\ 25 & 50 & 25 \\ - & 50 & 50 \\ - & 100 & - \\ - & 50 & 50 \\ - & - & 100\end{array}$

But the greatest difficulty of all perhaps is that a bull's grade is not known till he is at least five or six years old. How is this to be overcome? The pioneers adopted two methods; they kept their bulls till their grades, so to speak, were known-Hugh Watson's Old Jock won the sweepstakes at the Highland Society's Show at Perth when he was ten years old-and they bred from closely related animals. The former method was safest; the latter placed the chances on the right side, for there is a higher probability of the same characters being carried by near than by distant relations. But, just as the AberdeenAngus breed has been gradually made hornless, so, by constantly selecting the breeding stockthe bulls are the most important-from high grade cows a whole breed could be raised eventually to the highest milking capacity.

If the hybrids between high grade and 
low grade milkers were masqueraders, then apparently there would only be two grades of cows ; but two-thirds or so of one of the grades would be masqueraders. The difficulty again would be to find a bull that was pure high grade. Again there is only one test, the breeding test ; and in this case it might be summed up shortly by saying that if a bull is pure high grade, his daughters from both kinds of cows ought all to be high grade milkers.

One other character might be suggested, as an example. It has been found that the short legs of animals of North Devon type are dominant to the long legs of the Kerry. The same seems to be the case among Shorthorns and AberdeenAngus. That is, short-legged Shorthorns and Aberdeen-Angus are dominant to long-legged ones. That being so, there occurs in these breeds occasionally a long-legged animal, just as a red animal sometimes appears among AberdeenAngus. Bred to a short-legged beast, this animal's progeny will be short-legged, but not pure. It will be a masquerader. If it be a bull and put to short-legged cows, the progeny will also be short-legged, but half their number will be impure. If that bull be followed by another of similar character, a quarter of his progeny from the previous bull's daughters will be longlegged.

These are only two characters that might be 


\section{I44 EVOLUTION OF BRITISH CATTLE}

looked into, but there are others of importance which might be suggested, viz. :-

The capacity for fat production in milk;

The capacity for fatness and leanness ;

The presence and absence of black noses ;

The Shorthorn and the Aberdeen-Angus shape of rump ;

Thickness and thinness of skin ;

Longness and shortness of face;

The shape of the horns ;

A strong as against a weak constitution.

The subject must be left as it stands until future research has shown us still further into Nature's ways. 


\section{INDEX}

Aberdeen-Angus Cattle, 56, I24, I 32

Aberdeenshire Horned and Hornless Cattle, 52, 54

Alderney Cows, 76

Anglo-Saxon Cattle, $3^{8}$

Angus Cattle, $5^{2}$

Ayrshire Cattle, 108, 122

BaILey's description of Chillingham Cattle, 4

Bakewell, I Io

Banffshire Cattle, 55

Bede on the English Migration, 38

Bloxedge, I 13

Boece's Caledonian Bulls, 7

Bos longifrons, $\mathbf{1} 3, \mathbf{I} 5$

Bos primigenius, $\mathbf{I}$

Brindled Cattle, 84, 128

"Brown" Cattle, 83, 125, 127

Buchan Polled Cattle, 52, 130

Burghead Bulls, 63

CASAR's One-horned Ox, Elk, and Urus, 9

Caithness Cattle, 57, 66

Channel Islands Cattle, 65

Cheshire Black Cattle, 42, 75

Chillingham Cattle, 4

Colling, Charles, 123

Comet, 123

Crossing, I 1 2, 137

Culley's description of the Dutch imported Cattle, 77

Darwin, De Vries, and Mendel, 89,137
Darwin on Hornlessness, 45

De Vries, 90

Derbyshire Black Cattle, 42, 75, I I I

Devon Cattle, 42, 43, 100, I04, I I 5 , I 24

Devon Natts (Polled Cattle), 59, 64

Dobinson's Importations of Dutch Cattle, 78

Durham (the) Dun Cow, 5 I

Durham (old) Polled Cattle, 5o

Dutch (the) Cattle, 64, 7o, 75, 76, $77,89,102$, I 18,128

Egy ptian Horned Cattle, 29, 30

Egyptian Hornless Cattle, 67

Egyptian Long-horned Cattle, 30

Feral Cattle, 34

Fifeshire Cattle, 54, 56, 108, 128

Forfarshire Cattle, 52, 54

Galloway Cattle, 53, 59

Gloucestershire Cattle, 75, 76, I I I

Grading, 138

Green (J. R.) on the English Migra* tion, 39

Green's (J. R.) Line, 36

Gresley, Sir Thomas, II3

HaLF Longhorns, 78

Harting's List of Parks of "Wild" Cattle, 36

Hereford Cattle, 42, 43, 80, 89, 103, 104, 108 
Highland Cattle, 58, 84, 85, 100, 135

Hornlessness, 46

Hornless Cattle in Britain, 46, 61

Hornless Cattle in Holland, 66

Hornless Cattle in Northern Europe, 66

ICELAND Cattle, 66

In-breeding, 13, I 16, I18, 138

Ireland, 85, 104

Irish Polled Cattle, 6o, 108

Italian Cattle, 29

Jersey Cattle, 85,87

Kent Dutch Cattle, 75, 103

Kerry Cattle, 100

LANCASHIRE Black Cattle, 42, 75, II I

Lancashire Longhorns, 103

Lincolnshire flecked (Dutch) Cattle, $42,75,76,102$

Lincolnshire Red Cattle, 42, 43, I I I

Line Breeding, 140

Longhorns, $41,42,43,54,56,78$, $80,83,85,89$, I04, I05, I 21, I 28

MCKeNnY Hughes on the native British Cattle, I7

McKenny Hughes on the Roman Cattle in Britain, 26

Mackintosh, Brigadier, 106

Maoiles (the Irish), 60

Markham, Gervaise, 4I, 75

Mascal, Leonard, 43

Masqueraders, 97

Mendel and Mendelism, 89, 94, 118 , 140

Norfolk Cattle, 42, 43, 49, I04, 124

Normans (the), 64
Norse Cattle in the Channel Islands, Holland, Orkney, Shetlands, and Iceland, 65

Norse Cattle in Britain, 45

Norsemen (the), 62, 64

Northern (the) or Yorkshire Polls, 49

Norwegian Cattle, 67

OLD JOCK, 133

Orkney Cattle, 65

Roman Horned Cattle in Britain, 25

Roman Hornless Cattle in Britain, 69

Romans (the) in Britain, 32

Ross-shire Cattle, 57

Scandinavian Hornless Cattle, $66,126,128$

Scandinavian origin of British Hornless Cattle, 62, 65

Scott's (Sir Walter) Mountain Bull, 8

Scots Wild Cattle, 7

Scudamore's (Lord) importation of Dutch Cattle, 8I, 102

Scythian Cattle, 67

Shakespeare, a Longhorn Bull, II

Shetland Cattle, 65

Shorthorns, 4I, 54, 56, 80, 89, I04, I06, I22, 128

Skye Polled Cattle, 57

Somersetshire Polled Cattle, 60

Somersetshire Red Cattle, 75,76 , I04, II I, I 24

South European Cattle, 28

Staffordshire Black Cattle, 42, 76, I I I

Staffordshire Dutch Cattle, 8I

Suffolk (the) Duns, 47, 64, ror, I04, 124

Suffolk Red Cattle, 42, 43, IOI, I24

Sussex Cattle, 42, 43, I04

Sutherlandshire Polled Cattle, 57

Swedish Cattle, 68

Swiss Cattle, 85 
Townshend (LORD), 74, 108

Tull (Jethro), 74, 108

Twopenny, I I6, I 19

URUS (the), 9

Watson, Hugh, 132

Webster, of Canley, I 13

Welby, of Linton, I 12
Welsh Cattle, 76, 124

Weston, Sir Richard, 74

White Yorkshire Cattle, 122

" Wild" White Cattle, 3, 25

Wiltshire Red Cattle, 75

YORKSHIRE Black Cattle, 42, 75, 76, I I I

Yorkshire Polled Cattle, 49, 64

THE END

PRINTED BY WILLIAM CLOWES AND SONS, LIMITED, LONDON AND BECCLES. 

Half-Bound in Leather, Demy 8vo about 1000 pages, Illustrated. 21/- net; Post free 21/6 ; Foreign 22/-

\section{HISTORY}

OF

\section{SHORTHORN CATTLE.}

Edited by JAMES SINCLAIR.

The remarkable reception accorded to the volume by breeders of Shorthorns all over the world, and the high praise bestowed upon it by the Press, agree in describing the History as the most comprehensive yet published on its subject, and the standard work on Shorthorn Cattle. It deals not only with the History of the Breed in the British Islands, but also follows the fortunes of the Shorthorn across the seas to the Colonies and Foreign Countries, where it has made history in the great Cattle Breeding Industry. The best systems of management are fully dealt with, and altogether the work is well-nigh an indispensable companion to breeders of Shorthorn Cattle throughout the world.

\section{CONTENTS.}

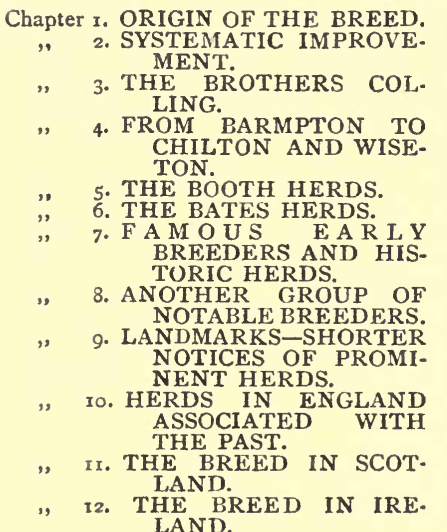
Chapter 13. THE BREED IN THE COLONIES AND FOREIGN COUNTRIES 14. SOME IMPRESSIVE SIRES, $1863-1898$.
15. REGISTRATION AND PEDIGREES. SHORT- HORN LITERATURE. 16. THE BREED IN THE SHOW-YARD.$$
\text { SHOW-YARD. }
$$$$
\text { 1) 17. CHARACTERISTICS OF }
$$ THE BREED.
18. SYSTEMS OF MANAGE-
" Ig. A REVIEW OF PRO- GRESS.
" 20. EXISTING HERDS IN THE UNITED KING- DOM.
Appendix. LIST OF SOME HIS- TORIC SALES. INDEX OF EXISTING HERDS IN THE UNITED KINGDOM. GENERAL INDEX.

Over 80 Illustrations of Famous Shorthorns, Portraits of Prominent Breeders, and Homes of the Breed.

\section{Standard Edition. Price 2I/- net; Post free 21/6; Foreign 22/=}

VINTON \& COMPANY, LTD., 8, Bream's Buildings, Chancery lane, London, E.C., England. 
PRICE 2I/- NET; POST FREE 2I/6 ; FOREIGN 22/-.

\section{HISTORY \\ OF}

\section{HEREFORD CATTLE.}

This handsome volume, half-bound in maroon calf leather, with lettering and ornamentation in gold, printed on specially made cartridge paper, and altogether produced in the highest form of the printer's and bookbinder's art, is the standard work on its subject. It is issued in an entirely new and revised form, under the Editorship of Mr. James Sinclair. The List of Contents indicate the remarkable scope of the publication. The Illustrations are a special feature, comprising portraits of breeders past and present, photographs of the homes of celebrated breeders, and numerous engravings of famous specimens of the breed. The History forms an invaluable practical guide, and well-nigh indispensable volume to breeders and all interested in the famous "Whitefaces" all over the world.

\section{CONTENTS*}

Chapter 1. Origin of the Breed.

2. The Pioneers and their Work.
3. Benjamin Tomkins, the Younger.
" $\quad$ 4. The Hewer and Jeffries Families.
5. A Group of Famous Breeders.
" $\quad$ 6. Progress of the Breed.
7. Later Improvement and Prominent Breeders.
" $\quad$ 8. Some Notable Herds in England.
" $\quad$ 10. The Breed's Extension.
" $\quad 11$. Systems of Management.
"12. The Breed in the Show-yard.
"13. Retrospect and Forecast.
"14. Existing Herds in the United Kingdom.

80 Illustrations, comprising Portraits of celebrated Breeders, notable Herefords, Homes of celebrated Herds, etc.

Price 21/= net; Post free 21/6; Foreign 22/=

VINTON \& COMPANY, LTD.,

8, Bream's Buildings, Chancery lane, London, E.C., England. 
Half-Bound in Leather, Demy 8vo, Illustrated. 21/- net; Post free 21/6; Foreign 22/-

\section{H I S T O R Y \\ OF \\ ABERDEEN-ANGUS CATTLLE}

This is an entirely new and revised edition of the "History of AberdeenAngus Cattle," originally written by Messrs. Macdonald and Sinclair, and published in 1882. The first edition has long been out of print, and the expansion and world-wide reputation of the " Doddies," demands that a more adequate chronicle should be available, alike in the interests of the breed and of the breeders. In the new edition edited by Mr. James Sinclair, all the valuable features of the original volume are preserved, while the history is completed to date, and more attention devoted to the progress of the breed in the United Kingdom, in the Colonies, and in Foreign countries. A new section is devoted to accounts of, including a List, of Existing Home Herds, while the Illustrations are a special feature, comprising portraits of leading breeders, homes of the breed, and of famous bulls and cows. In its revised form the "History of Aberdeen-Angus" is certain to prove of great service and value to all who are interested in this famous breed of Cattle.

\section{CONTHETS.}

Chapter 1. Origin of Domestic Cattle.

, 2. Polled Races of Cattle.

"3. Origin and Early History of Aberdeen-Angus Cattle.

" 4. Improvement of the Breed.

" 5. The Work of Hugh Watson, Lord Panmure, Earl of Southesk, W. Fullerton, William McCombie, Sir Geo. Macpherson Grant, etc.

, 6. Characteristics of the Breed.

7. Notes on some Early Polled Cattle.

8. Extinct Herds.

9. Notes on Herds in Scotland, England, and Ireland.

"10. The Breed in Foreign Countries and the Colonies.

"11. Leading Families.

" 12. Systems of Management.

") 13. The Breed in the Show-yard.

, 14. The Breed in the Sale Ring.

"15. Reviex of Progress.

"16. List of Existing Herds in the United Kingdom. Numerous Illustrations of Famous Aberdeen-Angus Cattle. Portraits of Prominent Breeders, and Homes of the Breed.

Price 21/=net; Post free 21/6; Foreign 22/=

VINTON \& COMPANY, LTD.,

8, Braam's Buildings, Chancery Lane, London, E. C, England. 


\section{LIVE STOCK HANDBOOKS.}

The Stock-breeder's Library.

This series covers the whole field of our British varieties of Horses, Cattle, Sheep, Pigs, etc., and forms a thoroughly practical guide to the Breeds and Management. The volumes can be had separately; each is complete in itself.

\section{1. - SHEEP : Breeds and Management. 6th Edition.}

By JOHN WRIGHTSON, M.R.A.C., F.C.S., President of the College of Agriculture, Downton.

\section{With 23 Full-page Illustrations.}

Contents-Effects of Domestication-Long and Fine Woolled Sheep-British Long-woolled. Sheep-Border Leicesters-Cotswolds-Middle-woolled-Mountain or Forest-Apparent Differences in Breeds-Management-Lambing Time-Ordinary and Extraordinary Treatment of Lambs-Single and Twin Lambs-Winter FeedingExhibition Sheep-Future of Sheep Farming-A Large Flock-Diseases.

\section{II.-LIGHT HORSES : Breeds and Management. 5th Edition.}

By W. C. A. BLEW, M.A. ; W. SCARTH-DIXON ; DR. GEORGE FLEMING, C.B., F.R.C.V.S.; VERO SHAW, B.A., etc.

\section{With 28 Full-page Illustrations.}

ConTents-Thoroughbreds-Hackneys-Cleveland Bays and Yorkshire Coach Horses-Arabians-American Trotters-Hunters-Hacks-Ponies-Asses and MulesManagement-Diseases and Injuries.

\section{III.-HEAVY HORSES : Breeds and Management. 4th Edition.}

By HERMAN BIDDELL ; C. I. DOUGLAS ; THOMAS DYKES ; DR. GEORGE FLEMING, C.B., F.R.C.V.S. ; ARCHIBALD MACNEILAGE; GILBERT MURRAY, and W. R. TROTTER.

With 29 Full-page Illustrations.

Contents-The Shire Horse-The Suffolk Horse-The Clydesdale Horse-The Breeding of Heavy Cart Horses for Street Work-The London Work Horse in Street and Stable-Farm Management of the Heavy Horse-Diseases and Injuries to which Heavy Horses are liable.

IV.-CATTLE: Breeds and Management. 6th Edition.

By WILLIAM HOUSMAN. The VETERINARY SECTION by

PROFESSOR J. WORTLEY-AXE.

With 33 Full-page Illustrations.

Contents-The Ox, Wild and Domesticatem) ( $x$ ) Original Species-(2) The Park Herds-(3) Changes under Domestication. ANCIENT HORNED BREeds: (I) Scotch Highland-(2) Welsh-(3) Kerry and Dexter-(4) Devon and South Hams(5) Sussex. IMPROVED HORNED BREEDS: Longhorn-Shorthorn-Hereford-Ayrshire. Polled Breeds: White Polled-Galloway-Aberdeen-Angus-Red Polled. Channel IsLands Brekds: Jerseys-Guernseys. ManaGement : ( $\mathrm{I}$ ) General Management-(2) Dairy Management and Records. Diseases of CATtLe, INDEX, etc.

V.-PIGS : Breeds and Management. 4th Edition.

By SANDERS SPENCER. With a Chapter on the Diseases of the Pig by Professor J. WORTLEY-AXE, and a Chapter on Bacon and Ham Curing by L. M. Douglas.

\section{With 20 Illustrations.}

Contents-Breeds of Pigs-Scales of Points-Selection of the Boar-Management of the Boar-Selection of the Sow-Management of the Sow-Mating-Management of Young Pigs-Exhibition Pigs-Breeding Cross-breds-Housing Pigs-Experimental Pig Feeding-Pig Census and Value-Diseases of the Pig-Bacon and Ham CuringIndex, etc.

$3 / 6$ each, by post $3 / 10$; or the set of five volumes, if ordered direct from the office, carriage free, $17 / 6$.

VINTON \& COMPANY, LTD.,

8, Bream's Buildings, Chancery Lane, London, E.C., England. 



\section{DAY USE}

RETURN TO DESK FROM WHICH BORROWED

EARTH SCIENCES LIBRARY on the date to which renewed.

Renewed books are subject to immediate recall.

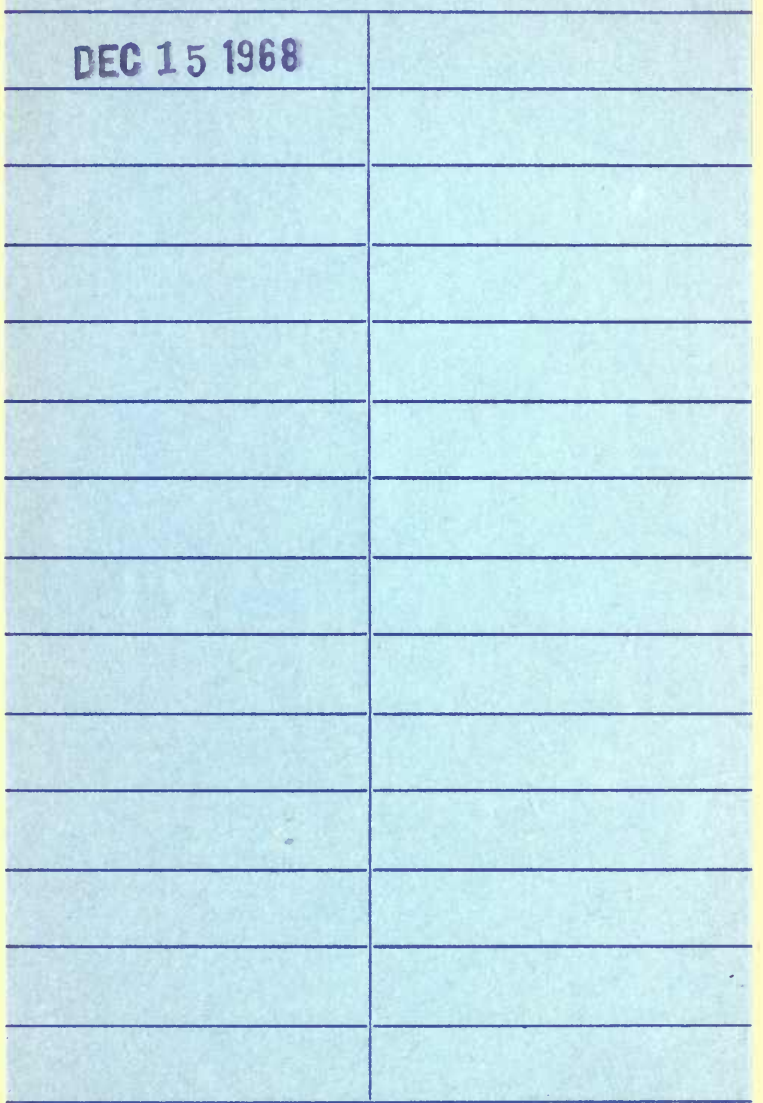

LD $21-50 m-6,60$

(B1321s10) 476

General Library

University of California

Berkeley 


$$
828
$$


